Illinois State University

ISU ReD: Research and eData

Theses and Dissertations

$12-16-2016$

\title{
Black Minds Matter: The Academic Identity of First Year African American STEM Students
}

Christa Dawn Platt

Illinois State University, cdplatt@ilstu.edu

Follow this and additional works at: https://ir.library.illinoisstate.edu/etd

Part of the Higher Education Administration Commons

\section{Recommended Citation}

Platt, Christa Dawn, "Black Minds Matter: The Academic Identity of First Year African American STEM Students" (2016). Theses and Dissertations. 701.

https://ir.library.illinoisstate.edu/etd/701

This Dissertation is brought to you for free and open access by ISU ReD: Research and eData. It has been accepted for inclusion in Theses and Dissertations by an authorized administrator of ISU ReD: Research and eData. For more information, please contact ISUReD@ilstu.edu. 


\title{
BLACK MINDS MATTER: THE ACADEMIC IDENTITY OF FIRST YEAR AFRICAN AMERICAN STEM STUDENTS
}

\author{
Christa D. Platt
}

\section{Pages}

A national push exists to increase the number of African American students who pursue STEM majors (Baber, 2014). While African American students have high aspirations to pursue STEM disciplines, an incongruence remains between their aspirations and their attainment of STEM degrees (Archer, Dewitt, Osbourne, 2015). This work seeks to critically underscore the structural issues that impede African American students in their journey as STEM majors. These impediments have been explored as factors that influence the identity of African American students. In the spirit of Critical Race Theory, the goal of this study is to give voice to first year African American STEM students who reflected on their pre-college experiences in school. Their experiences were collected and analyzed to understand, from the perspective of the students, the following: 1) structural issues in their educational journey and 2) how these structural issues impact academic identity as they complete their first semester of college. Seven students participated in this study. Each student wrote his or her STEM autobiography and participated in a one-hour interview. Students also were observed within the Louis Stokes Alliance for Minority Participation program, a National Science Foundation grant that supports underrepresented STEM students. These group meetings were observed with the purpose of understanding the culture and experiences of African American STEM students. 
The issues that emerged from this study revealed that teacher expectations, teacher quality, standardized testing, grades, and access to quality curriculum matter as they relate to the development of first year African American academic identity. The experiences students discussed are directly connected to the historical factors that have systemically plagued people of color in American history and American education.

KEYWORDS: Academic Identity, African American College Students, Critical Race Theory, Smartness, STEM 
BLACK MINDS MATTER: THE ACADEMIC IDENTITY OF FIRST YEAR AFRICAN AMERICAN STEM STUDENTS

CHRISTA D. PLATT

A Dissertation Submitted in Partial

Fulfillment of the Requirements

for the Degree of

DOCTOR OF PHILOSOPHY

Department of Educational Administration and Foundations

ILLINOIS STATE UNIVERSITY

2017 
Copyright 2017 Christa D. Platt 
BLACK MINDS MATTER: THE ACADEMIC IDENTITY OF FIRST YEAR AFRICAN AMERICAN STEM STUDENTS

CHRISTA D. PLATT

COMMITTEE MEMBERS:

Pamela Twyman Hoff, Chair

Beth Hatt

Lydia Kyei Blankson

Leroy Jones 


\section{ACKNOWLEDGMENTS}

This degree is a testament to the glory of God. In times when it was difficult to see His plan and light shining on me, He proved himself to be closer than I could ever imagine. In the words of an old spiritual song, He was there all the time. I vow to use this work and the work birthed from this dissertation to bring Him glory and honor. To my parents, Dr. Jonathan and Bobbie Platt, you infused the love of learning and love of people into my heart. Both of you are scholars, teachers, and full of wisdom. I will never stop aspiring to be like you. You helped to carry the weight of this process. Your love helped me win again. Your words helped me to do my first works over. Your strength and commitment to your Kingdom assignment helped me commit and stay the course of mine. This degree is yours. To my late grandparents: Roy William Platt, Cora Mae Platt and late Willie Davis, your legacy lives through me, and I proudly honor you. To my grandmother, Vennie Davis, you are a living legend, a doctor, a teacher, a preacher, a comedian, and our shero. To my favorite sister, LaWonta, you have been and always will be my best friend. You have been a rock for me throughout this entire experience. To Joe II, you have been a source of support and image of excellence and perseverance - and the perfect last minute editor. To my Joe III and my Jocelyn, you will always be my favorites. I expect you to take what you have seen us do and make it phenomenal. To my lifelong friend, Dr. Maya Rolfe, thank you for taking this journey with me and supporting me every step of the way---'you can call me Dr. Platt'! I am also indebted to my dear friends Tamekia and Angell, you both mean a great deal to me and were a refreshing source of sisterhood, comradery, and compassion. To my City of Refuge Family and LIFE Family, I do not know how I would have made it through this experience without your love, gifts, encouragement, support, and prayers. Finally, I would like to thank the members of my committee: Dr. Beth Hatt, Dr. Lydia Kyei-Blankson, and Dr. Leroy 
Jones. Each of you joined my journey to completion well before you were on my dissertation committee. Because of your support and belief in me as a scholar, you were chosen to be a part of my committee. Thank you for your support and each step you have taken with me during my journey. I am sincerely grateful. Lastly, I would like to my express deepest gratitude to Dr. Pamela Twyman-Hoff. You empowered me to get comfortable in my voice and settle in as a scholar. I am grateful to God for positioning you just at the right time to show up, remain, encourage, understand, and challenge. Most importantly, thank you for teaching me the power of my own resistance and how it can be used effectively to transform the way I see myself, the people I serve, and the way I carry out my work.

C.D.P 


\section{CONTENTS}

\section{Page}

ACKNOWLEDGMENTS

CONTENTS

iii

TABLES

vii

FIGURES

viii

CHAPTER I: SMARTNESS RETRACTION

Introduction

Statement of the Problem

Purpose and Research Questions

Theoretical Framework

Significance of the Study

Important Terms

Role of the Researcher

Chapter Summary

CHAPTER II: LITERATURE REVIEW

Introduction

Slavery

Deficit Myth

Legacy of Segregation and Desegregation

Racialized and Discriminatory Practices: Re-segregation 
The Educational Debt

Teachers

African American Secondary Experiences

Academic Identity

The First Year of College and Academic Identity

Conceptual Framework

Critical Race Theory

Chapter Summary

CHAPTER III: METHODOLOGY

Introduction

Purpose of the Study

Research Questions

Research Procedures

Recruitment of Participants

Data Collection

Participants of the Study

Cece

Bruce

Jacob

Jamiya

Leticia

Malcolm

Miracle 
$\begin{array}{lr}\text { Qualitative Techniques } & 50\end{array}$

$\begin{array}{ll}\text { Autobiographies } & 50\end{array}$

$\begin{array}{ll}\text { Observations } & 51\end{array}$

Session 1: STEM community development $\quad 52$

Session 2: Professional development 54

Session 3: Social gathering $\quad 54$

$\begin{array}{ll}\text { Interviews } & 56\end{array}$

$\begin{array}{lr}\text { Chapter Summary } & 60\end{array}$

CHAPTER IV: SCHOOL EXPERIENCES

$\begin{array}{ll}\text { Introduction } & 63\end{array}$

$\begin{array}{ll}\text { Narratives Matter } & 63\end{array}$

$\begin{array}{ll}\text { Teachers Matter } & 64\end{array}$

$\begin{array}{ll}\text { Bias and Expectations } & 64\end{array}$

$\begin{array}{ll}\text { Teaching Beyond the Classroom } & 68\end{array}$

$\begin{array}{ll}\text { Inspiration by Pedagogy } & 71\end{array}$

Tracking and Access to Quality Curriculum Matter 73

$\begin{array}{ll}\text { Chapter Summary } & 79\end{array}$

CHAPTER V: ACADEMIC INTEGRITY 81

$\begin{array}{ll}\text { Introduction } & 81\end{array}$

$\begin{array}{ll}\text { Academic Identity and Smartness } & 81\end{array}$

The Influence of Grades Matter $\quad 82$

Early Impressions $\quad 82$

$\begin{array}{ll}\text { Defined by Grades } & 83\end{array}$ 
Duality of Grades and Schooling $\quad 88$

$\begin{array}{ll}\text { Academic Identity Continuum } & 91\end{array}$

$\begin{array}{ll}\text { Identity Crisis } & 92\end{array}$

Identity in Conflict $\quad 93$

Identity Contingency 95

$\begin{array}{ll}\text { Identity Consciousness } & 97\end{array}$

$\begin{array}{ll}\text { Chapter Summary } & 99\end{array}$

$\begin{array}{ll}\text { CHAPTER VI: CONCLUSION } & 101\end{array}$

$\begin{array}{ll}\text { Introduction } & 101\end{array}$

Purpose Statement and Research Questions 102

$\begin{array}{ll}\text { Critical Reflections } & 105\end{array}$

$\begin{array}{ll}\text { Academic Terrorism } & 105\end{array}$

$\begin{array}{ll}\text { Shift Back to Consciousness } & 107\end{array}$

$\begin{array}{ll}\text { Implications of a Broken System } & 108\end{array}$

$\begin{array}{ll}\text { Future Research } & 108\end{array}$

$\begin{array}{ll}\text { Chapter Summary } & 110\end{array}$

$\begin{array}{ll}\text { A Call to Action } & 111\end{array}$

$\begin{array}{ll}\text { REFERENCES } & 113\end{array}$

APPENDIX A: LETTER OF SUPPORT, LSAMP APPROVAL 127

$\begin{array}{ll}\text { APPENDIX B: RECRUITMENT LETTER } & 128\end{array}$

$\begin{array}{ll}\text { APPENDIX C: CONSENT FORM } & 129\end{array}$

APPENDIX D: INTERVIEW QUESTIONS 131 


\section{TABLES}

Table Page

1. Participant Profiles

104 


\section{FIGURES}

Figure

1. Academic Identity Continuum

2. Academic Identity Venn Diagram
Page

92

99 


\section{CHAPTER I: SMARTNESS RETRACTION}

\section{Introduction}

Kimberly was a first year African American undergraduate student majoring in chemistry. She was a first year student who also participated in the Louis Stokes Alliance for Minority Participation Program, a National Science Foundation funded program that supports students of color who major in science, technology, engineering, and math (STEM). Prior to college, Kimberly was valedictorian of her high school, a predominately African American school in a large metropolitan school district. Although she excelled academically in high school, Kimberly repeatedly questioned her intellectual abilities during her first year of college. She barely maintained a passing grade in chemistry, which directly contrasted her high school experience of academic excellence.

Kimberly's academic challenges in college prompted her to consider the kind of preparation she received in high school. She questioned the quality of the curriculum and the expectations of her teachers, who were primarily white. In particular, she shared an experience from one of her Advanced Placement (AP) classes. When the time came for the class to prepare for the college credit exam, their teacher explained that students from their school typically did not pass the exam. The teacher decided to forego preparation for the AP exam; instead, she prepared the class for the ACT exam. Kimberly was troubled by her teacher's decision and thought it was based on the belief that Kimberly and her African American peers were not smart enough to pass the exam. What the school deemed an AP class started to feel more like a remedial course to Kimberly.

Kimberly encountered another teacher at her high school who explicitly warned her and her classmates not to think too highly of themselves because their white college counterparts 
were guaranteed to be smarter than them. The teacher's warning about their intellectual inferiority disturbed Kimberly and made her think twice about how she would perform at a predominantly white institution.

Before Kimberly entered college, she fought implicit and explicit messages of intellectual deficiencies. Eventually, these messages were reinforced during an office visit to her chemistry professor. During the visit, the professor told Kimberly it would be difficult for her to pass the class because she did not have a grasp of fundamental high school math. This news prompted Kimberly to reflect on the combination of deficit messages, racist comments, and disenfranchised educational practices that impacted her and her African American classmates during high school. As a result, Kimberly questioned whether she was smart enough to continue her STEM degree and deserved the title of valedictorian.

\section{Statement of the Problem}

There is a need to give voice to students like Kimberly, who are at the core of the nation's endemic issues of inequity, especially as they relate to access and upward mobility in science, technology, engineering, and math (STEM). Many students who begin their academic careers in STEM do not complete their degrees (Chen, 2009; Chen, 2013). For many of the students who leave, they choose non-STEM major and degree options (Chen, 2013.) Even more, the current narrative speaks to a great deficit in the number of people of color who pursue STEM majors (Chen, 2009; Chen, 2013).

The national STEM agenda calls for an increase in the numbers of people of color but lacks a much needed focus on the structural issues that limit them at each stage of the educational pipeline and ultimately, their access to careers in STEM (Baber, 2014). According to the Higher Education Research Institute (2010), underrepresented students and their counterparts 
are interested in and pursuing STEM upon entry of college at equal rates. Although African American students have been found to have high aspirations to pursue STEM degrees, the incongruence between aspirations and attainment has been attributed to their experiences of exclusion from science majors and careers (Archer, Dewitt, \& Osborne, 2015). In 2013, almost two million STEM degrees were conferred; of this number, $11 \%$ were earned by African Americans (National Center for Education Statistics, 2016). The data overwhelmingly suggests that African Americans lag behind their white and Asian counterparts (Higher Education Research Institute, 2010; National Center for Education Statistics, 2016). A goal of this study is to isolate the experiences of African American students to ensure their stories and critical experiences are not being lost in the politics of statistics and data. Gutierrez \& Dixon-Roman (2010) speak of the term "gap-gazing," which was coined to shed light on researchers' and analysts' infatuation with the numbers more that than the institutional, structural, and inequitable issues that influence and dictate the numbers. Educational researchers tend to stop right where the good work of understanding the data that speaks to marginalized student experiences are, which happens beyond the data (Gutierrez \& Dixon-Roman, 2010).

If African American students are to be compared to their white and Asian counterparts, there must be a comparison of their educational experiences in tandem. The Department of Education (2016) notes the lack of opportunity to prepare adequately for college STEM courses because courses like physics and calculus are not offered in schools that serve underrepresented students. Many students who attend schools that primarily serve students of color do not have access to Algebra II, a staple in the courses necessary for college readiness (Department of Education, 2014). In addition, African Americans make up only $10 \%$ of students in America enrolled in Advance Placement courses (Department of Education, 2014). These courses are 
paramount in ensuring students are successful in their first year of college (Higher Education Research Institute, 2010). Beyond policies, some people serve as gatekeepers to create and uphold barriers for students of color in their progression towards upward mobility (Berry, 2008). It has been well documented that the journey, with respect to academic achievement, aptitude and educational preparation, looks different for students of color in comparison to white students (Chen, 2013; Fischer, 2007). Limited access to critical literacy, high incidences of suspensions, zero tolerance disciplinary rules, high stakes testing, and lack of educational resources have been named among the practices and policies that disenfranchise students of color (Winn, 2011; Wilson, 2014). While schools are praised for making positive deposits into youth, some urban schools do not position students of color for success in their postsecondary educational experiences (Winn, 2011; Wilson, 2014; Zamudio, Russell, Rios, \& Bridgeman, 2011). Just as in Kimberly's case, low teacher expectations and limited access to courses that provide the foundation for college success can negatively influence a successful college transition (Dixson \& Rousseau, 2006).

By the time many African American students enter their first year of college, they have had many experiences that have shaped them; some of which are discriminatory and racially biased practices within the PK-12 system (Winn, 2011; Wilson, 2014). These experiences affect students' psyche, thereby impacting their self-confidence and ability to achieve academically (Steele, 1999). Howard (2003) asserts that pervasive negative labels are associated with students of color, both within the educational system and society, which tend to revolve around students being deemed as incompetent and deficient intellectually. Over time, these students become aware of labels associated with race, which makes it difficult for them to reconcile their personal perception with society's perception (Howard, 2003). 
A variety of educational interactions and school experiences with peers, friends, and educational leaders influence students' thoughts of self (Skipper, 2005; Schlosser \& Sedlacek, 2001; Hatt, 2012). According to Wenger (2000), the construction of an individual's academic identity is a twofold process wherein external factors make an impression first; then the student makes his or her own assessment based on external factors. The tranmission of the beliefs about the academic inferority of African American students over the course of the critical years of schooling may very well follow students into their first year of college, thus impacting their access to a college degree and a higher quality of life. This phenomenon has the far reaching power to impact the retention rates for colleges and universities. This reality establishes the need to study this phenomenon, especially as it pertains to African American STEM students.

\section{Purpose and Research Questions}

The purpose of this study is to learn through the lived experiences of first year African American students how their high school experience shaped beliefs about self and intellect. The study explores the ways in which high schools construct smartness and academic identity, specifically among African American students interested in pursuing science, technology, engineering and math. This study uncovers beliefs that can be found in the discourse about African American students, which is usually steeped in deficit discourse, whether genetic, cultural, familial, or environmental (Valencia, 2012).

The questions that guide this study are:

Guiding Question: What is the nature of the academic identities of African American college students with STEM majors and their connection to discourses of ability during their first year?

1) How do African American STEM students reflect and describe their high school experiences? 
2) In what ways did African American students' schools and educators contribute to selfperceptions about their intellectual abilities?

3) In what ways do the messages within their first year of college replicate or differ from the messages African American STEM majors received about their intellectual abilities from high school?

\section{Theoretical Framework}

This study draws on the theoretical underpinnings of Critical Race Theory (CRT) (Ladson-Billings \& Tate, 2006). CRT provides a keen lens that exposes racism and domination generally ignored when addressing the educational experiences of African Americans in the United States. Using CRT allows an explicit identification of the ways educators, policies, and structures have influenced African American students studying or considering STEM (LadsonBillings \& Tate, 2006). The foundation of CRT teaches that racism is a permenant part of American culture and can be found in any and all institutions (Ladson-Billings \& Tate, 2006). In addition, CRT argues that whiteness is a property and privilege (Taylor, Gillborn, \& LadsonBillings, 2009). Whiteness as a property is significant because the literature that speaks to STEM students tends to focus on the underachievement of African Americans and generally earmarks STEM for whites males (Berry, 2008). Another component of the theory requires those who have been a part of racialized systems to tell their counterstory to disrupt the bias narrative that has been told on their behalf (Solorzano \& Yosso, 2002). A counterstory gives voice to those who have been marginalized and often characterized negatively or misrepresented (Dixson \& Rousseau, 2006). This kind of narrative is important considering that the dominating discourse uses statistics as a means to justify discriminatory practices (Dixson \& Rousseau, 2006). The voices of people who have been marginalized are important because they offer a perspective 
often neglected and overlooked (Dixson \& Rousseau, 2006). While many stories are being told about African American students as learners, this study allows students to provide their voice and experience in STEM.

\section{Significance of the Study}

A discussion about increasing the numbers of underrepresented students in STEM has to start with an understanding of the K-12 experiences within American education, specifically in urban settings (Baber, 2014). Understanding the lived educational experiences of students is extremely important since in these experiences, students are influenced and conditioned for their futures (Wright, 2011, Solorzano \& Yosso, 2002). Baber (2014) notes that many policy makers, researchers, and educators are interested in increasing the numbers of underrepresented students in STEM; however, this project contends that any effort must have the hearts and minds of African American students at the center of the agenda.

This study helps disrupt the current discourse about African American students as learners. The disruption comes in moving away from questioning whether African American students can achieve, rather highlighting that the educational opportunities for African American students have never been on an even playing field (Zamudio, M., Russell, Rios, \& Bridgeman, 2011). Years of social justice movements or policy efforts have not been able to undo the power of hundreds of years of racism and injustice in the United States (Zamudio, M., Russell, Rios, \& Bridgeman, 2011).

This work looks to African American first year STEM students to provide a counternarrative that gives voice to the academic key players, their high school experiences, and their day-to-day realities (Wright, 2011). Like Kimberly, first year African American STEM students enter college with a personal reference they have learned about themselves in their 
schooling experiences. Understanding how these schooling experiences influence African American STEM students' transitions into college, specifically thoughts of their academic selves, leads the research agenda of this study.

\section{Important Terms}

Academic Identity: The ways we come to understand ourselves within and in relation to the institution of schooling and how this identity shapes our self-perceptions of efficacy, ability, and success in relation to academic potential, performance, and achievement (Hatt, 2012, p 439). Deficit Thinking: "A pseudoscience founded on racial and class bias. It 'blames the victim' for school failure instead of examining how schools are structured to prevent poor students and students of color from learning" (Valencia, 2010, p i).

Growth Mindset: A mindset that empowers students to embrace challenges and resist limits placed on their mental and learning capacity. Both students and teachers have the ability to possess this way of thinking (Dweck, 2006).

Fixed Mindset: A mindset that causes an individual to believe that intellect is innate and has limits. This mindset places limits on mental and intellectual ability. Both students and teachers can possess this way of thinking (Dweck, 2006).

Louis Stokes Alliance for Minority Participation: A program that supports "universities and colleges in their efforts to significantly increase the numbers of students matriculating into and successfully completing high quality degree programs in science, technology, engineering and mathematics (STEM) disciplines in order to diversify the STEM workforce" (NSF, 2013).

Smartness: "Something that is done to others (students) as a form of social positioning. Smartness is used as a tool by some not only to determine the social identities of others, but to make sense of their own identity" (Hatt, 2012, p 439). 
STEM: An acronym used for fields or majors concentrated in Science, Technology, Engineering, and Math (NSF, 2013).

Underrepresented in STEM: People who identify or are classified as African American, Hispanic, Native American, Native Alaskans, and Pacific Islander (NSF, 2013).

\section{Role of the Researcher}

As an African American woman primarily educated in predominately white educational institutions, I have learned what it means to have to protect one's self from negative messages projected from educators. I remember very vividly being taught to doubt my intellect. I learned very early on that, as the only black girl in the classroom, there was something different about me. I also learned rather quickly that my voice was not valued, credible, or wanted in class discussions. In my doctoral studies, I reflected on these and other educational experiences where my intellect was both interrogated and minimized. This reflection allowed me to uncover a kind of thinking about my intellectual capabilities. I believe this kind of thinking influenced me throughout my educational career. This kind of thinking influenced my fear of math and science. This kind of thinking kept me quiet in class, even when I knew the answer. It also kept me thinking I was not smart enough to participate in what I was convinced to believe were harder, unattainable subjects.

I was raised in a family that valued and supported education, but I never voiced the discriminating and marginalizing experiences in the classroom to my family because I was not aware of the magnitude of what was transpiring. I identify as a person who has suffered from educational trauma at the hands of those who, whether intentionally or unintentionally, helped to shape my beliefs about myself. Negative thoughts about my intellect and academic capabilities were projected onto me as a young child, under the tutelage of white teachers and led by 
institutional racism. Although I am an adult and have persevered through school, I am not totally free from these thoughts of self. I am currently fighting my way out; this dissertation is my fight. Telling the stories of African American students in STEM is my way of fighting back. Making students aware of the hegemonic forces that so easily try to dictate their confidence, self-worth, and academic identity is my fight.

In addition to my position as a researcher, my role with the participants is important to discuss. The students who served as participants in this study are a part of a program (Louis Stokes Alliance for Minority Participation) I oversee. My role as coordinator of this National Science Foundation program is administrative in nature and allows me to supervise a graduate assistant who handles much of the day-to-day responsibilities and mentoring of students. My role as their coordinator has been to provide opportunities for professional development, research opportunities, mentorship connections, peer networking, internships, and many more. My role as a researcher has been to immerse myself in the STEM community and learn about how these undestudents navigate their communities utilizing the messages they have learned about themselves during their pre-college experiences.

\section{Chapter Summary}

Understanding the discourse surrounding African American students and academic achievement, this study uncovers whether this discourse has influenced the minds of students who have recently exited secondary education and entered their first year of college. An underlying theme of who can be smart in STEM governs how many may view who can achieve in STEM (Berry, 2008). African American students going through the STEM pipeline need to provide their own narrative to help enlighten those in position to advocate for improving their experiences (Wright, 2011). 
The first year of college has been identified as the most critical year, as many who remain through the first year are more likely to be retained and graduate (Ostrove, 2007). According to Skipper (2005), many students have a drop in confidence during the first year of college. Even more, many students who enter college as a STEM major decide to change to a non-STEM major during their first year (NSF, 2013). With this knowledge, it remains imperative that the educational community understands how African American students feel about the way they have been trained to go through their first year of courses, specifically their STEM curriculum. Identifying the implicit and explicit messages is important, but understanding how these messages influence what African American STEM students believe about themselves as learners during their first year of college is paramount. The information provided in this study exposes what information students have learned about themselves in high school and explores how this information is utilized to navigate the first year in STEM. In the end, the expectation is to explore deeply how African American students utilize the messages they received about themselves to either move forward in their STEM disciplines or move away from their STEM disciplines. 


\section{CHAPTER II: LITERATURE REVIEW}

\section{Introduction}

A number of topical areas must be addressed in the literature to lay the foundation for this study. This chapter provides historical context of the great travail that African American learners have endured in a system that consistently has sought to obstruct their access to education. History clearly documents that white supremacist ideology has had a colossal impact on the educational experiences of African Americans (Anderson, 1988). Some of the most detrimental have been the prohibiting of literacy, the mishandling of tender souls during the desegregation era, and present-day systemic inequities within the educational system. All are among the many transgressions that point to deliberate, systematic indoctrination of white supremacy and black inferiority (Williams, 2005; Anderson, 1988; Morris \& Morris, 2002; hooks, 2003; Woodson, 1933; Dubuis, 1968). Although history shows an agenda to indoctrinate African Americans with destructive teachings of inferiority and subordination, history also reveals a resilient, unrelenting people fighting to protect their humanity through education (William, 2005; Anderson 1988; Bullock, 1967).

In addition to these historical atrocities, this chapter speaks to present-day realities of racialized and discriminatory practices within the educational system that shape the experiences of African American learners. Finally, this review discusses the concepts of academic identity, smartness, and the intertwining of race and racism.

\section{Slavery}

Slavery was not only designed to physically detain, but also to mentally and emotionally apprehend African American people (hooks, 2003). Tactics like the color caste system that propagated the notion of Blacks having smaller, inferior brains systematically relegated African 
Americans to the lowest form of humanity (hooks, 2003; Gould, 1981). These tactics not only made them inferior in the minds of Whites but also were intended to negatively affect how African American people felt about themselves (hooks, 2003).

Enslaved Africans were labeled genetically inferior without the capacity to learn, and laws were instituted to prohibit their access to education (Watkins, 2001). It was against the law for whites to teach enslaved Africans to read and write (Williamson, 1999). Although clear laws against the education of enslaved Africans existed, these resilient souls found ways to fulfill their desire to learn (Bullock, 1967; Webber, 1978; Williams, 2005). Enslaved Africans found learning and whites caught teaching them were in danger of grave consequences (Williamson, 1999). More severe punishment was reserved for the enslaved by way of torture, flogging, dismemberment, and murder (Williamson, 1999; Bullock, 1967; Webber, 1978; Williams, 2005). Enslaved Africans took ownership of their learning by teaching themselves and educating their fellow enslaved brothers and sisters (Williams, 2005). They took great pride in their education, held literacy as a badge of honor, and defied the notion of their said incapability to learn (Williams, 2005; Webber, 1978).

Slave states, mostly southern, enacted legislation to control the impending domino effect of educated free and enslaved people of African descent (Williams, 2005). The free, enslaved, and white masters understood that literacy was equivalent to liberation. Freedom for the enslaved meant they would no longer be held physically captive, and more specifically, their hearts and minds would no longer be controlled by White slave masters (Williams, 2005). Whether enslaved or free, African Americans continued to gain ground in literacy through teaching one another, underground schooling, and distributing anti-slavery materials, all of which were against the law and carried stiff consequences (Williams, 2005; Butchart, 2010). 
While most of the educational efforts came from within, African Americans began to find support from the Freedman's Bureau, an organization of European missionaries enlisted to help in their educational movement (Anderson, 1988). Unfortunately, the level of investment and motives varied among Whites who participated in educational training; not all were for the advancement of African American people (Butchart, 2010; Anderson, 1988). The abolishment of slavery did not cancel the tenets and pervasiveness of white supremacy. Educational practices directed by many white philanthropists were unequal, segregated, and intended to reinforce a subservient African American class (Watkins, 2001; Woodson, 1933; Naidu, 2010; Anderson, 1988). Anderson's (1988) depiction of the Hampton Normal school model reveals a calculated method where African American students were brainwashed to believe that they were inferior, immoral, and in need of European guidance and instruction (Anderson, 1988). This doctrine of inferiority was based on the ideology that African Americans were mentally sound and possessed the capacity to learn but morally incapable to lead in political positions and in need of Europeans to teach them how to be moral (Anderson, 1988). This indoctrination was intended to leave African Americans with a mindset to revere other races and cultures as well as internalize a disdain for themselves (Woodson, 1933; Cole, 2007).

\section{Deficit Myth}

To understand the current experiences of African Americans in education, it is important to investigate the sociocultural construction of race in America. The driving force behind slavery, the Hampton model, and educational exclusion of African Americans was an ideology that continually, comprehensively, and systemically depicted and falsified an intellectually strong people as a genetically, intellectually inferior people in American society (Mutegi, 2013). Without question, racism, bias, and prejudice have been embedded in the fabric of society as 
well as in the construction of research, theories, and science (Gould, 1981). Unfortunately, research influenced by societal norms that goes unchallenged or devoid of critique often leaves those impacted by its findings vulnerable to faulty, misguided, and dangerous policies (Gould, 1981). The commonly held social belief about African Americans was they were biologically inferior to whites (Gould, 1981). Even worse, it was believed that they were a degenerate form of humanity or possibly a part of a totally different species (Gould, 1981). Commoners, presidents, government officials, and leaders of the "scientific research" community held these beliefs (Gould, 1981).

Mutegi (2013) argues that this kind of ideology set the precedence for the unavoidable systems, policies, and structures that African Americans have to suffer through, sometimes succumb to, and navigate. Racially discriminatory beliefs like those of racist researchers, bigoted political figures, and prominent leaders have been interwoven in American society (Mutegi, 2013). The ideology that African Americans are genetically inferior and thereby intellectually deficit can be found in the policies, procedures, systems, and structures in American education (Valencia, 2012; Mutegi, 2013). The level of educational preparation that African American students currently receive is intertwined with the historical ideas and assumptions regarding their intellectual capacity; educational policies have been enacted based on a concocted theory of incompetence and genetic inferiority (Mutegi, 2013). In particular, Civis (1993) speaks to an educational document from the early 19th century that discouraged giving African Americans a fair, equal education since they were considered mentally incapable of handling it. Although the manifestation of this kind of ideology still exists, researchers are not explicitly exposing the racist agendas linked to America's past racial terrorism against the hearts and minds of African Americans (Mutegi, 2013; Gould, 1981). 


\section{Legacy of Segregation and Desegregation}

The sociocultural construction of race cannot be overlooked when discussing the current condition of education (Mutegi, 2013). It is imperative to look back to the policies and practices enacted that reinforced racism and white supremacy to understand the current state of education for students of color. Not only did white supremacy and domination dictate the educational process for African Americans during slavery, they also governed the laws and policies of the land for hundreds of years following. Through the landmark case of Plessy v. Ferguson (1896), the United States entered a period when Jim Crow laws were enacted to legally institute separate public facilities where non-White citizens were relegated to subpar eating facilities, restrooms, drinking fountains, and schools (Guthrie \& Springer, 2004). Unequal educational practices manifested in these separate African American schools as second hand buses and books as well as underfunded, dilapidated facilities (Morris \& Morris, 2002).

Through resistance, African American advocates won a counter victory with the historic Brown v. Board of Education case, which legally overturned Plessy v. Ferguson (Williamson, 1999; Guthrie \& Springer, 2004; Bell, 2004). However, Critical Race theorist Derrick Bell (2004) argues that the display of racial tension and exclusionary practices was seen as detrimental for global relations and the international image of the United States. Therefore, the decision to pass Brown was a guise of equal rights and a face-saving political tool for the American government (Bell, 2004). At its core, the decision was not intended to protect the lives

of those who experienced educational discrimination from the American government but to spare America from global embarrassment (Bell, 2004).

Today, it is clear that parallels exist between the passing of Brown and the current agenda to diversify STEM. The current agenda, on the surface, is to expand STEM participants beyond 
primarily white and male students but, at the core, neglects the needs of people of color and ignores the structures and systems that perpetually exclude and disenfranchise them (Baber, 2014). The drive to diversify has been primarily a function of global positioning and economic gains rather than an agenda of equity (Baber 2014; Basille \& Lopez, 2015).

The pseudo efforts to create equity for African Americans through the passing of Brown caused a pseudo implementation of the law (Bell, 2004). One of the major faults with the Brown decision was the language Chief Justice Earl Warren used, which was ambiguous and interpreted in a variety of ways throughout the nation (Bell, 2004; Guthrie \& Springer, 2004). Although it was found unconstitutional to uphold separate educational facilities based on race since it would be detrimental to the psyche and emotional state of African Americans, Judge Warren's arbitrary instructions to desegregate the schools "with all deliberate speed" did not ensure the immediate action to desegregate (Bell, 2004; Guthrie \& Springer, 2004). While celebrations ensued among African Americans and supporters of equal education, many states challenged the ruling and delayed the implementation of Brown (Guthrie \& Springer, 2004). As prominent educational leader W.E.B. Du Bois (1968) foreshadowed, whites did not readily implement the Brown decision for years; subsequently, the educational futures of both African American and white children were jeopardized.

The hope of Brown was for it to be the start to change the course of educational disenfranchisement of African Americans; however to 21st century students, the Brown decision is null as segregation remains a major issue within the P12 system (Ladson-Billings, 2006;

Kozol, 2005). Present-day schools resemble those from the Jim Crow era: separate and unequal with many underfunded schools being heavily populated with low income and minority students (Ladson-Billings, 2006; Kozol, 2005). However, in the segregated schools of the Plessy era, 
African American teachers were devoted to a racial uplift that inspired, encouraged, and strengthened the hearts and minds of students (hooks, 2003). Per Judge Warren, desegregation was meant to counter feelings of inferiority and protect the "hearts and minds" of African American students; African American students' "hearts and minds" were indeed influenced, but not necessarily for the better (Morris and Morris, 2002; hooks, 2003).

Upon desegregation, many African American parents were left with concerns about the impending psychological trauma awaiting their children (Morris and Morris, 2002; hooks, 2003). African American parents were concerned about whites teaching their children to believe they were not smart, they were the exception to the rule, or to deny their identity as an African American (hooks, 2003; Morris \& Morris, 2002). Desegregation took African Americans from safe environments, which strengthened their racial pride and individual self-value, and brought them into spaces of constant mental, verbal, and physical battles within an educational system built on racist and discriminatory practices (hooks, 2003). In the public eye, Brown was praised for its efforts, even amidst the delayed implementation and white resistance while others were concerned that this movement would bring about the "collective murder of black souls" (hooks, 2003 p.12).

The often unfriendly, unaccepting environments of desegregated schools experienced by both parents and students were a complete shift from the nurturing, caring, and family-oriented schools they were familiar and comfortable with (Morris \& Morris, 2002; hooks, 2003). The transition to segregated schools often meant that students who were emotionally and socially supported were forced into fear and stress induced environments (hooks, 2003). In addition, educational needs went unmet for African American students. For instance, gifted black boys 
experienced intellectual castration as their scholarly identity was stripped from them; ultimately, they were excluded from gifted courses (hooks, 2003).

Not only were gifted boys denied their right to equal education, but African Americans students as a whole were at risk of being labeled inferior and incapable by virtue of the pervasiveness of white supremacist ideology (hooks, 2003; Morris \& Morris, 2002). The Hampton model of creating educational boundaries for African Americans resurfaced during desegregation as many students were tracked into technical and industrial training rather than academic and college tracks (Bell, 2004). In fact, many African American students could not escape what Woodson (1933) refers to as two distinct educational outcomes for whites and African Americans, in that whites were supported, strengthened, and encouraged through stories about their superiority that were told and retold while African American people were perpetually labeled as inferior and unable to meet educational standards.

\section{Racialized and Discriminatory Practices: Re-segregation}

\section{Standard Reforms}

American education's history of standards based testing and school tracking has been linked not only to social policies and pseudo-science but also to white supremacy ideology (Valencia, 2012; Reddy, 2007). Educational policy makers used the work of scientists to create stories to link heredity and intellect to legally disenfranchise students of color (Valencia, 1997; Valencia, 2012; Reddy, 2007; Osgood, 2010). Racial marginalization in education stems from an often untold era of American history that includes the strategic plan to systematically eradicate racially, mentally, and physically “defective” humans (Valencia, 2012; Reddy, 2007; Osgood, 2010). 
The eugenics movement, grounded in white supremacy ideology, labeled and positioned non-white persons along with the mentally ill and poor people as inferior (Gould, 1981). This belief marked them as problematic and detrimental to society and humanity (Valencia, 1997; 2012). These groups of people, considered as socially poisonous, were sterilized, sometimes unknowingly, to ensure a physically and mentally fit society (Reddy, 2007; Osgood, 2010). The guiding belief system propagated genetics as a determinant of one's ability, behavior, and capacity to learn (Gould, 1981). Under this belief, various tests and measurements were constructed, many of which failed, to build a case to substantiate this pseudoscience (Gould, 1981; Valencia, 1997; Reddy, 2007).

During this era, eugenicists endorsed IQ testing to track students into their said predestined futures (Reddy, 2007). Eugenicists used the IQ test as a single determinant of a person's intellectual capacity against the warning of the scientist who created the assessment (Reddy, 2007). Although the IQ test was never intended to serve as a gross generalization of smartness, eugenicists capitalized on their agenda and began to develop educational testing, health screenings, and mental assessments as a means to sort and categorize society (Osgood, 2010). From government to teacher education training programs to curriculum in high schools as well as colleges and universities, eugenics ideology was widespread, well received, and considered a socially acceptable practice (Reddy, 2007; Seldon, 2007; Osgood, 2010).

American history documents a longstanding tradition of white supremacist ideology, which constructed an intellectual hierarchical system and positioned African Americans and other non-whites at the bottom tier (Anderson, 1988; Valencia, 2012; Reddy, 2007). This tradition manifested in multiple ways; the present-day methods that sort and categorize students of color were fully instituted within the American education system well before the 20th century. 
When African American students entered integrated schools, they experienced the ideologies of slave masters, eugenicists, and segregationists who sought to place limits on their educational capacity (Valencia, 2012). People of color have been labeled inadequate and blamed for the misfortune they have experienced; meanwhile, white supremacy ideology proponents have been exonerated of their detrimental negative contributions to generations of people of color (Reddy, 2007; Valencia, 2012).

\section{Tracking}

American education still relies on the practices informed by eugenics, insomuch that African Americans tend to be labeled as inferior learners through practices like tracking (Ansalone, 2006). Tracking is the practice of categorizing students into groups based on a variety of factors (Oakes, 1985). Some factors include test scores, arbitrary teacher bias, predictions about the student's future, and beliefs about student abilities (Oakes, 1985). While many teachers prefer tracking because it simplifies the management of classroom dynamics, typically, students tracked to upper level courses benefit as these sections allow for the exploration of complex ideas and critical thinking (Ansalone \& Biafora, 2004; Ansalone, 2006). Research indicates that African American students tend to be tracked in lower courses, leaving them susceptible to low expectations from teachers, subpar curriculum, and higher rates of drop out incidences (Oakes, 1985; Ansalone, 2010; Werblow, Urick, \& Duesbery, 2013 Mickelson \& Everett, 2008). A student tracked into lower courses is likely to take on the identity of the track

they are placed into, which impacts their self-concept as learners (Ansalone \& Biafora, 2004). African Americans and other students of color have been overwhelmingly tracked in lower tracks and disproportionately tracked into courses for special needs (Blanchett, 2006). While proponents of tracking argue that the process of determining a child's track is strategic and 
systematic, it has been found that a student's placement can be directly correlated with the personal perceptions and biases of school officials (Oakes, 1985; Blanchett, 2006). Students' placement can determine their educational future as well as limit their access to career opportunities, all of which are left in the hands of arbitrary decision making practices. It has been argued that these practices are influenced by white supremacy and racism, thereby reinforcing longstanding issues of racial inequalities in society (Blanchett, 2006). Inevitably, tracking is a tradition strongly upheld, but rarely dissected for its true intentions and historical roots (Oakes, 1985).

A large part of the problem stems from beliefs about who African Americans are as learners and people in general; these beliefs can be found in the language surrounding African American children in schools, which is usually steeped in deficit discourse, whether genetic, cultural, familial, or environmental (Valencia, 2012). African American children, families, and communities have been blamed for what is considered their own academic problems (Valencia, 2012). The language that permeates the dominant discourse consistently points to the deficiencies of African American learners; however, new voices have emerged that identify the lack of equal educational opportunities (Darling-Hammond, 2007; Finkel, 2010). The onus for the achievement gap has been placed on African American children whereas the opportunity gap has been charged to the inequities within the education system (Darling-Hammond, 2007; Finkel, 2010). African Americans have paid an awful price within the educational system, and reforms in education must be redirected from blaming students and families to taking responsibility for the debt they have accumulated to create educational barriers for generations of African American people (Ladson-Billings, 2006). 


\section{The Educational Debt}

The discourse of blame, which has charged African American people for their educational issues, has failed to account for the historical, socio-political, and economic catastrophes that, added together, produced the educational debt (Ladson-Billings, 2006). The historical debt has been described as the compilation of events that primarily surround the overwhelming prohibition of education for African Americans, Latino Americans, and Native Americans. Included is the phenomenon of slavery, which excluded African Americans from education for hundreds of years, the failure of the Brown vs. Board of Education, genetic inferiority labeling, unequal schooling during the Jim Crow era, and unfair treatment during the days of desegregation (Ladson-Billings, 2006). The next component of the debt is the sociopolitical debt, which is described as the nation's exclusion of minorities in political and social processes (Ladson-Billings, 2006). In addition to exclusion from voting rights, LadsonBillings (2006) highlights the common practice of denying minorities the opportunity to participate in quality education initiative decision-making arenas such as parent teacher associations and school board initiatives.

In addition, Ladson-Billings (2006) speaks to the economic debt. She notes that students who live in affluent neighborhoods are offered more resources, the best teachers, and newest technologies, thereby have an advantage over students born into families of lower socioeconomic status, many of whom are African American and Latino. This unequal disbursement of funding is based on the longstanding policy that schools are funded by local property taxes (LadsonBillings, 2006). Kozol (2005) notes that low-income communities have the insurmountable task of providing sufficient revenue for their schools because their property is "virtually worthless" (p $5)$. 
The disparity found in educational funding within the P12 system is in schools all over the country; however, schools in Chicago, New York, and New Jersey have grave inequities in the spending between urban and predominantly white schools (Kozol, 2005). Suburban school districts can spend between $\$ 4,000$ and $\$ 9,000$ more per student than urban and minority schools (Kozol, 1991; Kozol, 2005).

The debt associated with funding students at different levels not only impacts their individual educational opportunities, but the manifestations can be seen in the inequalities that translate into higher rates of low income and students of color attrition rates and under preparedness (Kozol, 2005). According to Koyama (2007), "students who are marginalized, constrained, or have limited access to school contexts - through institutionalized practices, policies, and ideologies - are far more likely to disengage academically, to 'resist' schooling, and forgo college attendance" (p. 2315).

The totality of the historical, social, political, and economical debt challenges the country to acknowledge its responsibility to rectify the impact in the lives of African American people (Darling-Hammond, 2007). Unfortunately, instead of focusing on the legacy that includes the mistreatment, abandonment, and disfranchisement of many populations, a constant and continual reverberation of blame points to African American learners and their families (Valencia, 2012; Darling-Hammond, 2007; Ladson-Billings, 2006).

\section{Teachers}

The educational debt speaks to the economic debt that impacts that quality of teachers that students have access to. Teachers are vital to the entire educational experience as student experiences hinge on encounters with their peers and teachers; these can be either positive or negative. African American students in the United States are said to primarily be taught by 
Caucasian teachers, as they make up more than $80 \%$ of teachers (United States Department of Education, 2016). As student diversity increases, the educator workforce must reflect the changing demographics (United States Department of Education, 2016). Even more, the mental models and biases of teachers, whether white or any other race, play a role in how students experience school (Milford \& Tippett, 2013). Teachers with a frame of reference that places race as a determining factor for learning and excellence can also be found in science education. In their study, Milford \& Tippett (2013), found the mental models of pre-service teachers were tied to Eurocentric ideas and images of who could be a scientist. What then is to be said for the experiences of African American students who have teachers who hold these hidden ideologies of whiteness and maleness as characteristics of scientists? According to Kane (2012), teachers must understand that there is more to the classroom than learning the content; students are learning who they are or are not as scientists. The teacher has a great influence on development of students identities in STEM classrooms (Kane, 2012). If African Americans students are to be legitimized in the schools as great candidates for science, teachers must be in position to move passed the ideas that only a "certain type' of student can be successful in STEM (Milford \& Tippett, 2013; Kane, 2012). The frame of reference teachers bring into the classroom colors the way they teach, engage, and challenge students of color. To what extent do students of color "feel" the impact of a teacher that has disqualified them from science by virtue of their race? Stairs, Donnell, \& Dunn (2011) note "teachers who believe that certain students cannot succeed in school because of particular attributes (e.g., they are Black or Hispanic, poor, or non-native English speakers) operate from a deficit perspective" (p. 6). Students who unknowingly meet teachers at their point of bias are at-risk for being excluded from the possibilities of believing they can love and learn STEM. 
A means for teachers to check their biases is to commit themselves to what LadsonBillings (1995) calls culturally relevant pedagogy. She lists the following as the foundation upon which good teaching rests:

“(a) Students must experience academic success;

(b) students must develop and/or maintain cultural competence; and

(c) students must develop a critical consciousness through which they challenge the status quo of the current social order" (p.160).

Teachers who wish to commit to this level of teaching must first believe that all students can succeed. Before they can teach students to develop and maintain cultural competence as well as a critical consciousness, they first must be committed to these tenets themselves. Murrell (2001) suggests that successful teachers in urban school settings are considered "community teachers." These teachers "draw on a richly contextualized knowledge of culture, community, and identity in their professional work with children and families in diverse urban communities" (p.4). They are not solely concerned about what is happening within the class, but they care about all that comprises the student's experience. Holistically, the student's family, community and academic community are all a part of their experience. Most importantly, an understanding that students and their whole selves have much to contribute to the classroom must exist. Both Murrell (2001) and Ladson-Billings (1995) argue that student voices and their experiences are prime resources for tools of teaching. African students all too often are seen in a dark shadow of deficiencies; teachers are in the position to ensure that students know their value, worth, and abilities. First, teachers must be willing to see them. 


\section{African American Secondary Experiences}

The secondary experiences for African American students institutionally reveal the inherent discriminatory practices within the American educational system (Howard, 2003; Ladson-Billings, 1999; Solorzano \& Yosso, 2002; Valencia, 2012). For example, LadsonBillings (1999) speaks of "disproportionate expulsion rates, tracking into vocational or nonacademic programs, and limited access to advanced placement opportunities" (p. 9). African American students do not have access to the same opportunities and resources that white students are exposed to (Finkel, 2010). Some of the most detrimental practices suffered by students of color are the educational policies and practices based on deficit thinking (Solorzano \& Yosso, 2002; Valencia, 2012). Deficit thinking suggests that disadvantaged and students of color experience academic failure because they are intellectually inferior and are to blame for their inadequacies (Valencia, 2012). In essence, this theory discounts the inherent, racist practices within subpar curriculum, instruction, and funding disparities and relegates the problem to African American students and families (Ladson-Billings, 2009).

African American students are not naïve to discriminatory practices, such as the lack of academic rigor, low touch administration, poor instruction methods, lack of college preparation guidance, and expectations of failure with their schools (Nasir et al., 2009; Thompson, 2002). As early as elementary school, African American students can lose interest in reading because of limited and outdated books (Thompson, 2002). When students must continually, repeatedly contend with negative messages that surround race and education, it can adversely effect their psyche through internalization of these messages (Steele, 1999). Over time, the knowledge of these practices influence how students experience school and specifically effect African American students' psyche by creating doubt in their ability to achieve academically (Steele, 
1999; Howard, 2003). Students have a keen awareness of how race negatively influences interactions with their teachers and administrators (Howard, 2003).

Urban schools, with populations rich with students of color, are not rich with the advantages of quality and diversity of courses that condition success in standardized testing and, thereby, college preparation (Klugman, 2013). While the achievement gap is the focal point for reformists, a true point of focus must explore the disparity in opportunities in courses, considering those most prepared for post-secondary work have access to quality high school courses (Edmunds, 2012; Darling-Hammond, 2010; Finkel, 2010).

Advance Placement (AP) courses are also unequally distributed within the American education system, with an unfair advantage given to more affluent and white students, with three times the number of courses and diversity in course offerings (Klugman, 2013). Many African American students do not have access to AP courses; when they do, they do not have the same access as their white counterparts (Klopfenstein, 2004). When schools populated with low income and minority students increase the few AP selections they have, their privileged counterparts also increase their AP course options and bring college courses onto their campuses (Klugman, 2013). In turn, the gap of inequity is not resolved but managed (Klugman, 2013). African American students are excluded when it comes to this kind of exposure and access to Advance Placement. AP courses allow students to not only be prepared for college, but also to have a grade point average higher than the typical 4.0 (Klugman, 2013). According to the Department of Education (2014), students of color do not have the competitive edge in curriculum or grade point averages for college admittance (Zamudio, Russell, Rios, \& Bridgeman, 2011). This disparity is an example of the structural issues that truly impact the educational progression and success of African American students. At the core exists a system 
governed by racist practices that perpetually disenfranchises African American people (Zamudio, Russell, Rios, \& Bridgeman, 2011).

Success in college has been equated to high school preparation, grades, and access to higher levels of curriculum (Adelman, 1999). While these are the staples that prepare for a successful college career, there are disparities in minority students' pre-college preparation (Roderick, Nagoaka, \& Coca, 2009; Nasir, McLaughlin, \& Jones, 2009; Edmunds, 2012; Darling-Hammong, 2010; Finkel, 2010). Specifically, African American students consistently have been underrepresented in Advance Placement courses and receive minimal college preparation guidance (Klugman, 2013; Roderick, Nagoaka, \& Coca, 2009; Klopfenstein, 2004; Solorzano \& Ornelas, 2004). Conversely, African American students have been overrepresented in remedial education, special education, and emotional behavior disorder tracks (Harry \& Klingner, 2007). In STEM, low teacher expectations of African American boys have the ability to stand between the students and their access to upper level mathematics classes (Berry, 2008). $=$ African American students are placed in positions of great challenge when excluded from opportunities that are tightly coupled with access to college (Solorzano \& Ornelas, 2004).

In addition, educational reforms in the United States have mandated teachers to prepare students for high stakes testing (Heilig \& Darling-Hammond, 2008; Au, 2009). In their study, Heilig and Darling-Hammond (2008) note that the implementation of high stakes testing resulted in high school students being retained and an increase in dropout rates for minority students. High stakes testing educational environments "increases pressures and anxieties" as well as eliminates the exploration of cultural and student identities (Au, 2009, p. 70). It is important for African American students to have access to education that brings their worldview to the forefront of the curriculum (Au, 2009). Teaching practices become ineffective when solely 
focused on teaching to the test while disregarding culturally relevant techniques in spaces of African American students (Au, 2009).

\section{Academic Identity}

There are deep cultural and historical roots within the educational system that cannot be ignored when seeking to understand the mechanisms and practices that inform and shape a student's identity (Murrell, 2007; Howard, 2003; Hatt, 2012). Students are not only learning educational material, they are being taught who they should believe they are, unbeknownst to them (Wenger, 2000). The construction of an individual's identity does not happen in isolation; rather, a variety of factors, spaces, and people has the ability to make significant contributions (Welch \& Hodges, 1997; Wenger, 2000). In her work on mindsets, Dweck (2006) has studied academic identity construction. This work is paramount as it gets to the heart of how students see themselves as learners. In particular, students either view themselves as having an endless capacity to learn or believe there is a cap on their intellectual abilities.

Wenger's (2000) assertion that identity does not happen in a vacuum lends us to believe that educators with unchecked biases have the capacity to look, impose, and project their ideas of who can or cannot be smart onto students. This ability is dangerous because students can learn how to quit and concede because their teacher places limits on them, not because they cannot excel (Dweck, 2006). Academic identity has been defined as "the ways we come to understand ourselves within and in relation to the institution of schooling and how this identity shapes our own self-perceptions of efficacy, ability, and success in relation to academic potential, performance, and achievement” (Hatt, 2012, p 439). Hatt (2012) notes this process leaves students to learn about who they are by interacting with teachers, administrators, and peers, all of whom bring their experiences, knowledge, and biases into the new world of the classroom. 
Holland's (1998) Figured World Theory suggests that students experience ongoing encounters that include displays of preferential treatment, privilege, and use and abuse of power; all of which are available for students to make meaning of who they are and what position they should play. A number of studies rely on Holland's (1998) theory to describe a state of emergency that urban children are in as it relates to the formation of their academic identities (Urrieta, 2007; Rubin, 2007; Hatt; 2012). This emergency calls for the rescue of students of color who are at greater risk of being unfairly classified by adults as deficient and unintelligent (Rubin, 2007; Hatt; 2012). According to Holland's (1998) Figured Worlds theory, the risk does not stop at students being categorized and treated unfairly by the powers that be; the most devastating risk comes when students start to believe and act out beliefs that have been forced onto them. If bias, prejudices, racist ideas, and practices are not exposed and rectified, the ubiquitous process of academic identity development leaves African American student identity in jeopardy of external and internal assassination. Howard's (2003) study reveals teacher stereotypes and racialized perceptions of students caused a heightened awareness and concern for the African American students. The students specifically were concerned that their teachers viewed African American students as "ghetto" and unable to learn, which led them to believe that teachers were unwilling to effectively teach black students (Howard, 2003). The manifestation of this belief caused many to feel defeated in their learning process, even when their academic identity was once positive (Howard, 2003).

Dweck (2006) calls attention to the ways in which students and educators view their academic abilities and capacity. In many ways, she suggests that students learn about who they are as learners through the shaping practices of educators. Students are said to either have a fixed or growth mindset. Having a fixed mindset means that one believes that he or she is born with all 
the intellectual capacity that her or she will have, so a cap exists on ability (Dweck, 2006). On the other hand, students with a growth mindset believe that no challenge is too difficult and their brain has the ability to expand to learn any subject and overcome any challenge. The root of either mindset is based on one's belief about their ability (Dweck, 2006). These two ways of viewing oneself is extremely important as it relates to academic achievement. If a student does not believe he or she can learn challenging subjects like STEM, they will likely succumb and avoid trying. On the other hand, students with a growth mindset are prone to excel in hard subjects and tasks, making coursework in STEM doable and attainable (Dweck, 2006).

Wenger's (2000) assertion that academic identity does not happen in a vacuum lends us to believe that educators with unchecked biases and fixed mindsets have the capacity to look, impose, and project their fixed mindset onto students (Dweck, 2006). This projection is dangerous as students can learn how to quit and concede because their teacher places limits on them (Dweck, 2006). When discussing matters related to African American students, it is important to include how race and racism impact identity. Dweck (2006) does not speak to the intersection of race, racism, and the development of an African American student's mindset. Therefore, Dweck's (2006) work neglects the impact that race and identity as well as the role of racism in shaping of minds of African American students.

Academic identity development happens at a time when students are able to identify their aptitude to complete tasks within an academic setting, a most critical time in a student's life (Welch \& Hodges, 1997). According to Okeke, Howard, Kurtz-Costes, \& Rowley (2009), the most significant chance to influence the identity of a child is during childhood and adolescence. The question remains whether traces of a student's developed academic identity can be found in the African American college student experience. It is important to know whether a negatively 
altered academic identity follows a student to the college lecture hall. The stigma of academic inferiority over the course of the critical years of schooling may very well translate into retention issues for colleges and universities.

This leads the discussion of academic identity into the dynamic interplay between the construction of academic identity and racial identity that African Americans experience within schooling (Murrell, 2007). African American students experience a world where they have been racialized and minoritized to the degree that there is a need to resist the pressure to become what the dominating discourse seeks to impose. Stanley (2007) argues a master narrative found in literature and history seeks to promote a message of inferiority for those who are and have been historically oppressed. Travailing through the educational system with this kind of narrative, without succumbing, requires proactive resistance (Hoff, 2016; Murrell, 2007). With the number of challenges that African American students face within their school environment, it stands to reason why it is necessary to take an attitude of resistance for the protection of one's psyche (Murrell, 2007). African American students are engaged in what could be considered an all-out war on their academic identity as detailed in Zamudio, Russell, Rios, \& Bridgeman's (2011) work.

"Students of color do not have the advantage of walking into a classroom as individuals: they walk in as black, brown, and red persons with all the connotation such racialization raises in the classroom. They do not walk into a classroom where the curriculum embraces their histories. They walk into a classroom where their histories and cultures are distorted, where they feel confused about their own identities, vulnerabilities, and oppressions. There is no level of liberal reforms that can alter these experiences for 
students of color without directly challenging the larger systems in society" (Zamudio,

Russell, Rios, \& Bridgeman, 2011 p. 18-19).”

In the midst of understanding the complexities of the educational experiences of African American students, there cannot be a neglect of the ways in which race and racism shape not only these experiences, but who the students are (Murrell, 2007).

Because students construct their academic identities during a sensitive time, it is imperative for PK-12 educators to be aware of the dynamic interplay between race and racism as well as their impact on policies, procedures, and interactions, in light of the academic identity construction of African American students. Within this construction is the danger of African American students learning and endorsing the notion that Whites have more academic ability than Blacks (Okeke, Howard, Kurtz-Costes, \& Rowley, 2009). Since K-12 is the time where pathways are created for certain groups, taking on this false ideology as truth has the potential to influence how African Americans engage their curriculum and can subsequently affect how they are tracked (Okeke, Howard, Kurtz-Costes, \& Rowley, 2009). When considering the prominent and pervasiveness of racism in American culture and the education system, there is a clear and present danger for African American student identity, which is at risk while encountering an unfair, unjust educational system. The academic identities of many African American STEM students are at risk if institutions of education are not aware of how bias and discrimination can be subtle, pervasive, and destructive at the same time (Berry, 2008).

\section{The First Year of College and Academic Identity}

Higher education is viewed as one of today's greatest commodities. Individuals with four-year degrees are intended to have access to career opportunities and a higher quality of life in comparison to those who do not (Kuh et al, 2008). Unfortunately, many students begin their 
careers in higher education only to leave before earning a college degree (Kuh et al., 2008; Tinto, 2001).

Unanimously, researchers have indicated the first year as the most critical year of college (Terenzini, 1995; Ostrove, 2007; Tinto \& Engle, 2008). Students who continue to their third semester of college are stated to have a greater chance of graduating (Ostrove, 2007). Colleges and universities have used this information to invest an abundance of resources to support students in the critical first year (Barefoot, 2005). For many institutions, this support includes first year experience programs, learning communities, and experiential opportunities to ensure higher retention (Barefoot, 2005; Goodman \& Pascarella, 2006). The investment made for the support of first year students has yielded impressive retention results for many institutions (Ishler \& Upcraft, 2005).

To successfully complete the critical first year, all students are required to mentally, physically, and/or culturally transition from high school to college (Tinto \& Engle, 2008). A successful transition requires students to adjust to their new college environment, polices, and curriculum (Tinto \& Engle, 2008). First year students are expected to recognize and address a variety of challenges, including study skills, time management skills, and interpersonal relationships (Clark, 2005). Students have been given a mandate, regardless of their background, to find their place within the campus environment by establishing their sense of belonging through classroom, faculty, and peer engagement (Anderman, Freeman, \& Jensen, 2010). Doing so gives students greater odds of having a positive academic experience (Anderman, Freeman, \& Jensen, 2010).

Clark (2005) notes that negotiating the transition to college is a multifaceted process; however, students categorized as underrepresented have more challenges to negotiate than 
majority students (Terenzini, 1995). Kuh (et. al, 2008) suggests that underrepresented students are "at risk" for leaving the institution at higher rates than their counterparts. Some of the pinpointed challenges are under preparation, financial strain, and issues with campus climate (Ishler, 2005; Tinto, 2001). However, at the core of the American education system are historical and structural issues that have deep roots in racism and injustice, with present day implications for students of color (Harper, Patton, \& Wooden, 2009; hooks, 2003; Jackson, 2007; Anderson 1988).

American colleges and universities have a dark legacy of excluding people of color as these institutions were established and inculcated with white supremacist ideology and domination (Anderson, 1988; Harper, Patton , \& Wooden, 2009). Institutions of higher education have not outrun the roots of their past in that the reoccurring question of "worthiness of African Americans in education" continues as a mainstay in educational discourse (Harper, Patton , \& Wooden, 2009, p. 403). When African American students entered Historically White Institutions in the 1960s, a racially tumultuous time, there was a critical need to unite to form Black Student Unions, peer tutoring programs, and informal peer academic advisement to inform students of racist professors (Williamson, 1999).

Present-day African American students still need these bonds of unity as trauma awaits them upon entering the worthiness questioning culture of Historically White Institutions (Smith, Allen, \& Lynette, 2007). They may not enter an environment of blatant racism and discrimination like those of the 1960s; however, it is very likely for them to experience "racial discrimination in covert and informal ways" (Feagin, Vera, \& Imani, 1996). African American students are liable to experience invisibility, invalidations, and insensitivity to racial issues at the hands of students, staff, and faculty (Feagin, Vera, \& Imani, 1996). Smith, Allen, \& Lynette 
(2007) studied the experiences of 36 African American men at predominantly white institutions (PWIs) and discovered they were labeled and treated as "predators, cheaters, personal threats, violence prone, thieves, incompetent, violators, and/or subhuman" (p. 573). Having multiple negative and racist interactions would automatically make any person feel unwelcomed. Even more, a closer look is needed to understand how these kinds of interactions impact the academic identity of first year African American students.

In addition, Watkins, Labarrie, and Appio (2010) interviewed ten African American students who attended a PWI. Their study found that all of the students identified with experiencing microaggressions from staff, faculty, and students (Watkins, Labarrie, \& Appio; 2010). These students were made to feel inferior, less intelligent, and unwelcomed in their college environment (Watkins, Labarrie, \& Appio; 2010). If they were, by chance, received into the campus culture, it was because they were considered a token or rare find within their race. They rarely were allowed to be individuals as many were asked to be a spokesperson for their race. These students not only had to contend with and manage their emotions, they also had to consider how to bring light to those who presented these views (Watkins, Labarrie, \& Appio; 2010).

One of the most critical issues for first year students focuses on their ability to successfully transition into the institution (Clark, 2005). Drilling the needs of first year students to a mental, physical, and cultural transition and adjustment has been a mainstay recommendation for successful strategies of student persistence (Tinto \& Engle, 2008). However, when a collection of racial assaults, wounds, and mental stressors shape the experiences of African American students, a clarion call is needed to reevaluate who and what actually needs adjusting within the campus community (Feagin, Vera, \& Imani, 1996; Smith, 
Allen, \& Lynette, 2007). The conversation must move from recommendations of assimilation for students of color to a closer look at the interplay between members of the campus community and how policies and procedures impact the experiences of African American students (Feagin, Vera, \& Imani, 1996; Smith, Allen, \& Lynette, 2007).

\section{Conceptual Framework}

\section{Critical Race Theory}

American educational reform has focused on the inadequacies of minority students evidenced in the discourse regarding closing the achievement gap while underlying issues related to opportunity remain under analyzed (Nasir et al., 2009; Thompson, 2002; Darling-Hammond, 2007; Finkel, 2010). Some of these underlying issues include lack of academic rigor, high suspension rates, underfunding, low touch administration, poor instruction methods, lack of college preparation guidance, and expectations of failure with their schools (Nasir et al., 2009; Thompson, 2002; Darling-Hammond, 2007; Finkel, 2010).

This study uses Critical Race Theory (CRT) as the framework because of the overwhelming lack of discussion in STEM on race. CRT concludes that racism is a permanent part of American society, especially within structures and policies of the education system (Ladson-Billings G., 2006). CRT allows the elephant of race to be addressed head on and explicitly. Racism is a permanent part of society and can be found in plain sight (Ladson-Billings $\&$ Tate, 2006). For the purpose of this study, CRT is used to illuminate how race and racism within pre-college experiences influence the shaping of first year African American students' academic identities in STEM.

A critical solution to address and eradicate these ills can be explored through CRT for strategy on how to challenge these discriminative norms and practices found in educational 
research. CRT suggests that racism is a fact of life and is embedded in the fabric of our culture, institutions, school systems, politics, and government (Taylor, Gillborn, \& Ladson-Billings, 2009; DeCuir \& Dixson, 2004). CRT calls upon scholars to reject what has been taught historically and question everything with a critical lens (Harper, 2009; Ladson-Billings, 2009; Taylor, Gillborn, \& Ladson-Billings, 2009). Birthed out of Critical Legal Studies (CLS), CRT's focus is to take what CLS started, to include racism as a factor to study from a multidisciplinary perspective (Harper, 2009; Taylor, Gillborn, \& Ladson-Billings, 2009). CRT has been used to expose racism in law, education, and the public sector (Ladson-Billings \& Tate, 2006). CRT redefines racism as a concept that is institutionally ingrained and espoused, not as a single act (Taylor, Gillborn, \& Ladson-Billings, 2009).

CRT also speaks to the idea that whiteness is a property (Taylor, Gillborn, \& LadsonBillings, 2009). With this tenet comes the idea that whites are entitled, privileged, and thought to be superior to other races (Taylor, Gillborn, \& Ladson-Billings, 2009). With STEM, it is imperative to understand how whiteness as a property operates in the understanding of "who" has been deemed to be smart in STEM and who has been excluded.

The lens of CRT clearly depicts STEM exclusion. CRT questions access to rigorous curriculum, lack of diverse teachers, harmful tracking practices, and low expectations (Zamudio, Russell, Rios, \& Bridgeman, 2011). While many search for answers to fix and resolve the perceived issues of African American students, it is imperative that what is fixed and resolved is the historical reference that lives in the sociocultural construction of race in America (Taylor, Gillborn, \& Ladson-Billings, 2009; Valencia, 2012). African Americans have been negatively characterized for centuries through the lens of racism and hatred; therefore, researchers cannot afford not to explicitly pinpoint how this legacy impacts present-day issues in education (Mutegi, 
2013). Furthermore, the legacy of white supremacy and eugenics, both steeped in racism and social construction of race, manifests presently in countless ways.

Most importantly, this study seeks to learn the lived experiences of students and hones in on CRT's tenet of counterstory to tell the stories of African American students (Solorzano \& Yosso, 2002). Counterstory is useful for "exposing, analyzing, and challenging the majoritarian stories of racial privilege" (Solorzano \& Yosso, 2002, p. 32). Much of the narrative about African American students is negative and steeped in deficit (Valencia, 2012). The African American student experience should be captured by individual and collective experiences that speak to the true realities of navigating the educational system. These experiences cannot be captured in statistical data that generally problematizes the African American student. (Dixson \& Rousseau, 2006). This study would not be complete without stories that expose the realities African American first year students face in STEM prior to college and during their first year.

\section{Chapter Summary}

The trauma experienced by the African American people has an overwhelming message of disdain for their humanity, their hearts, and their minds. This history includes slavery that excluded African Americans from education for hundreds of years, the failure of Brown vs. Board of Education, genetic inferiority labeling, unequal schooling during the Jim Crow era, and unfair treatment during the days of desegregation (Ladson-Billings, 2006; Valencia, 2012). It also includes present-day policies, procedures, systems, and structures that hold African American students as genetically and, thereby, intellectually inferior (Valencia, 2012; Mutegi, 2013). Without question, racism, bias, and prejudice are embedded in the fabric of society as well as the construction of research, theories, and science (Gould, 1981). It is a great concern that African American students travailing the current educational system are in the care of a 
broken system that seeks to indoctrinate African Americans to hold other races and cultures in high esteem while internalizing a disdain for themselves (Woodson, 1933; Cole, 2007). Academic identity is a direct reflection of the experiences had in schools. The transmission of the beliefs about the academic inferiority of African American students over the course of the critical years of schooling has the potential to follow students into their first year of college, thus impacting their access to a college degree and a better quality of life. This study uncovers the practices and experiences that have had a guiding effect on the academic identity of first year African American STEM students. 


\section{CHAPTER III: METHODOLOGY}

\section{Introduction}

This study explores the pre-college experiences of first year African American STEM college students and how these experiences influence the construction of their academic identity. Since the first year is the most critical year of the college experience (Tinto, 1997), it remains even more important to learn how students utilize their constructed academic identity to navigate their first year experience. The question remains whether students have received negative messages about their academic identity prior to entering their new college environment and whether these messages are reintroduced within the campus community.

\section{Purpose of the Study}

This study gives voice to the lived experiences of African American first year STEM college students. Their voices are key to understanding what they have learned about themselves and their capacity in STEM. The study examines the pre-college experience of African American students to understand how this information either helps or hinders their progress in their STEM majors. Using Critical Race Theory as the guiding theoretical framework, this study seeks is to understand how African American STEM students experience the development of their academic identity with a focus on racial bias and mental models.

\section{Research Questions}

The following questions guide this research:

Guiding Question: What is the nature of the academic identities of African American college students with STEM majors and their connection to discourses of ability during their first year?

1) How do African American STEM students reflect and describe their high school experiences? 
2) In what ways did African American students' schools and educators contribute to their self-perceptions about their intellectual abilities?

3) In what ways do the messages within their first year of college replicate or differ from the messages they received about their intellectual abilities from high school?

\section{Research Procedures}

\section{Recruitment of Participants}

Students in the study were recruited because of their status as first year African American STEM students. Purposeful sampling technique was utilized as participants were recruited because of their membership in the Louis Stokes Alliance for Minority Participation (LSAMP) program at a midsize public Historically White Institution (Merriam, 2009). LSAMP is a National Science Foundation grant funded program that supports underrepresented students in STEM (NSF, 2013). Students participate voluntarily to receive benefits, such as belonging to a community of students of color studying STEM, receiving faculty mentoring, academic coaching, and academic and professional development workshops.

The Principle Investigator of the LSAMP program at the midsize Midwest University granted permission to identify and recruit LSAMP students. It is important to note that I serve as the coordinator of the program in addition to being the primary researcher in this study. I function primarily as an administrator while the contact and face of the program is the LSAMP graduate assistant.

One hundred and thirty-eight first year African American students were eligible for the study. All LSAMP students received an invitation letter via email to participate in the study. To reduce coercion and undue influence, the research methodologist and advisor sent the invitation email. Although the students' primary LSAMP contact is the graduate student, not myself, it was 
important to control for conflict of interest issues within the study by having the methodologist as the sole distributor of the recruitment email. The recruitment email explicitly stated that participation in the study would not influence their participation in LSAMP.

Seven students were elected to participate in the study. Six of the seven students were participants of the LSAMP program. The six participants were told that their participation was optional and not a part of the LSAMP programming or procedures. Although the seventh student was not in LSAMP at the beginning of the study, the student joined the program at the close of the interview after learning of the program's benefits.

All participants were informed that they had the right not to participate in the study and if they decided to participate, they had the option to withdraw from the study at any point. LSAMP members were told that their participation in the study would not influence their participation in LSAMP in any way.

The recruitment letter included a link for participants to indicate their interest. All students received two gift cards for their participation to local restaurants for $\$ 20$ total. Compensation was disbursed twice throughout the study. Students received a $\$ 10$ gift card after they submitted their autobiography and the second $\$ 10$ gift card at the close of their interview. All students in the study were told they could withdraw from the study at any point.

\section{Data Collection}

There were three separate formats of data collection. First, the participants were asked to write a reflective academic identity autobiography. Autobiographies allowed for a "recount of an individual's experiences with various forms of racism" (Solorzano \& Yosso, 2002 p. 33). Those who had been marginalized and oppressed were called upon to disrupt the racist narrative with their personal accounts (Solorzano \& Yosso, 2002). Autobiographies are often used to connect 
the student's experiences to larger, complex social issues within the education system (Bell, 2003). Autobiographies were used to create individualized questions for the semi-structured interviews in addition to the protocol. The second part of the data collection was a semistructured 45-60-minute interview. Semi-structured interviews allowed for participants to be asked follow up questions (Merriam, 2009). The freedom to move beyond prescribed questions is valuable, especially when exploring the depths of a personal and cultural experience (Merriam, 2009).

The participants' autobiographies were used as a baseline for the follow up questions. The goal was to use the autobiographies for deeper reflection on the culture and players that influenced their thinking about themselves during their high school career. In addition, it was important to understand whether or not their culture, feelings, and experiences in high school were similar or different during their first year of college. Questions were asked to allow participants to think about their current mindset and how they learned to think/believe within their identified mindset frame (Dweck, 2006). The interview allowed students to discuss the messages they received in high school about who they were as learners and determine whether they identified similar messages in college, specifically in STEM courses. In addition, a focus was placed on their experiences with smartness as it relates to how they view themselves as African American STEM students.

Finally, because the students were recruited as a result of their eligibility and membership in the LSAMP program, there were opportunities to observe their interactions with other students in STEM. These observations were unstructured and occurred at workshops hosted by the LSAMP graduate assistant. The primary reasons student-to-student observations were unstructured is due to the exploratory nature of the study and my role as a coordinator in the 
LSAMP program. Unstructured observations gave the opportunity to witness how students interact with their STEM peers, curriculum, and during STEM building exercises (Mulhall, 2003). The field notes from the observations were used as part of data collection; they were reviewed and analyzed along with the autobiographies and interviews.

\section{Participants of the Study}

Seven students elected to participate in the study. The original goal of having a balanced ratio of students was met with three men and four women participants. The participants of the study are introduced below using pseudonyms:

Cece. Cece is a Biology major who credits her academic success to her mother's determination to return to school for her dental assistant and dental hygienist credentials. She also finds pride in her mother instilling a love of reading, exploration of the arts through museums, and enriching STEM opportunities. Cece spent her K-8 years in private schools and experienced a considerable amount of success. She was one at the top of her class. However, upon graduating from eighth grade, Cece's mother decided to move her and her daughters from their large metropolitan, majority Black and Latino school district to a suburban, white, wealthy district.

Cece's new school challenged her in ways that she had not been challenged. She learned that there was a clear difference between her private school in terms of the curriculum, teachers, expectations and that of her new public school district. Her first semester caused her to feel like she did not belong and as though she was not smart enough. It would prove to be a positive experience for Cece as she pushed herself to overcome these feelings, worked hard to learn what she was not exposed to in her private school, and engaged in new, exciting opportunities within her school. Her first semester in college was surprisingly positive. Much of the material in her 
first year STEM she recognized from her high school AP courses. Cece had a great deal of confidence facing her STEM courses and earned a B average at the conclusion of her first semester.

Bruce. Bruce is an Information Technology (IT) major who recently switched his major from Biochemistry. His original goal was to be a pharmacist, but he ran into what he considered challenges, such as not being accepted into another school, his ACT score, first semester "C" level grades, and other students' perceived enjoyment and success in chemistry coursework. Pharmacy was Bruce's desired major because of his love for science and the possibility of making a good living. He will continue to pursue a STEM degree in IT as he believes it will be a better fit and easier for him to earn higher grades. Bruce admits that his course load was difficult and, at times, proved overwhelming. He took three STEM classes and one general education course. He has a strong family educational background as both of his parents have graduate degrees. Even still, Bruce sees himself as a reflection of his ACT score and average grades, which challenge his ability to see himself as smart.

Jacob. Jacob was a Physics Engineering major at the start of his first year of college. He chose this career path during his first year of high school primarily because his mother encouraged him and told him of its high earning potential. Around the time of the interview, Jacob decided to move from a STEM to a non-STEM major. He based his decision on the level of difficulty within his STEM classes. Jacob lost interest in Physics as it grew more challenging. He also had a schedule that included majority STEM classes and one general education course. Despite the challenges in his courses and grades he earned, Jacob did not waiver in the notion of whether or not he was smart. Jacob remained confident in his ability to excel in college, even if he was moving away from STEM. Even though Jacob speaks with confidence, he was impacted 
by structural issues within the school system. Jacob's story includes multiple moves to different states where he experienced different types of schools. He attended two high schools, one he considers the "diverse school" and the good school while he described the "black school" as a distraction that did not have AP classes, resources, etc. The latter is the school from which Jacob graduated; he noted they did not have what he needed to properly prepare him because they lacked the curriculum of his previous school. Jacob believes that if he would have had these types of classes, his first semester would not have been as difficult. Jacob found himself on academic probation after his first semester, having failed his STEM courses.

Jamiya. Jamiya is a biology major concerned about her status as a student. She leads with the notion that she is not doing well in school. Her transition into college has been challenging. She knew college was different from high school, but she expected to at least earn a $\mathrm{C}$ average in her classes. To her dismay, Jamiya earned below average and failing grades. Aside from her grades, she was proud to be working on campus and making good friends. A large part of Jamiya's interest to major in STEM is from her high school experience. She likens her desire to pursue STEM to her teachers and their care for her.

In contrast, Jamiya did not receive that same care in her K-8 experience. Her formative educational years were riddled with what she considered bullying by her teachers. This bullying was attributed to her being labeled by a teacher who once taught her older brother and sister who were seven years her senior. Jamiya's concern is she never had a chance to be excited about school and learning because she was never expected to succeed. These thoughts and feelings plagued her first semester of college as she was in a perpetual mental battle of whether or not she was able to excel or even motivated to do the work. Jamiya failed all of her classes her first 
semester and contemplated not returning to the university but returned to retake the same course load during the second semester.

Leticia. Leticia is an agriculture major who originally explored a career as a veterinarian but decided to focus on a career in animal science. Her desire for science related topics have been a part of her daily life through her interactions with animals and personal pets. Leticia's first semester in college consisted of exploring student organizations, meeting new people, and discovering herself. Although Leticia is finding her way in college, she reflects on her high school experience, in particular, the notion of her school being a college preparatory school. Leticia does not believe her school prepared her for college and compares her education with that of her peers in courses. Her first year semester proved challenging in some areas, specifically chemistry because she does not recognize any of the curriculum, even though she took a chemistry class in high school. Leticia earned a $\mathrm{C}$ average at the close of the semester.

Malcolm. Malcolm is a biochemistry major who is set on becoming a dentist. He has a full scholarship. He takes pride in being an African American student on full academic scholarship but is equally frustrated when his peers are surprised by his academic performance and accomplishments. Malcolm believes that he has to work as hard, if not harder, than his white counterparts in college. He received this message from his mother, who was aware of the school system where Malcolm attended. She explicitly told Malcolm that he was going to enter a Predominantly White Institution where other students would have received a better education. Malcolm took this urge from his mother seriously and worked consistently during his first semester of college to prove he was capable of competing. Malcolm earned a B average at the close of the semester and will continue in his STEM degree. 
Miracle. Miracle is a chemistry major who attributes her decision to pursue STEM to her high school teachers. She has a strong affinity to her high school and considers those within it as additional members of her family. Her motivation to become a pharmacist comes from closely watching her grandmother succumb to cancer. Her goal is to create medicine that cures cancer, and she takes great pride in being an African American woman who might conduct this groundbreaking medical feat. This pride also comes with an anticipation that she will face racism and discrimination because of her identity as an African American woman; to some extent, she welcomes it.

A large part of Miracle's goal is to make a difference by building a platform that causes people to listen and change their minds about who African American women are. Her strong foundation in high school, where she studied issues of social justice along with her STEM curriculum, set her on a path to participate civically by breaking societal molds and stereotypes. At the end of the semester, Miracle was on academic probation but she earned C's in her STEM courses and did not fail any courses. According to Miracle, her grades do not define who she is; she is fully aware that her definition of being smart works outside of societal definitions, which solely focus on grades.

\section{Qualitative Techniques}

\section{Autobiographies}

Students who participated in the study were asked to answer two questions prior to having their interview. Due to scheduling conflicts, two of the students did not complete the autobiography prior to their interview; however, five students completed the research sequence as requested. Each student was asked to reflect on the following questions: 
1) Before College: Can you describe one day or one event from your past that made you especially feel you could be a STEM major? Please share a detailed account of where you were, the people involved, and what was said?

2) Before College: Can you describe a time in your past when you did not feel like you belonged in STEM? Please share a detailed account of where you were, the people who were present, and what was said?

The purpose of having students reflect prior to the actual interview was to allow them to get connected with their experience in STEM, their STEM stories, and the key players. Overall, the interviews flowed easily and students picked up from their written statements through follow up questions that asked them to go deeper into their experiences. One drawback from having autobiographies occurred when students were asked to give detailed accounts; one student provided great detail while most students gave a short version of their experience. While still valuable, detail was not present in the autobiographies. However, the use of the follow up interview with the baseline information from the stories allowed for greater detail and understanding. The purpose of autobiographies is often used to make connections between the student's experiences to larger, complex social issues within the education system (Bell, 2003). Although the stories were brief, clear connections existed between their experiences, teachers, grades, standardized testing, and their identity. These themes are spoken of as sources of significance in the next chapter.

\section{Observations}

The observations for the study occurred at LSAMP bi-weekly meetings. These meetings focus on providing a support network for students. Most of these events allow students to converse about current events, either guided by the LSAMP graduate assistant or introduced by the students. These meetings help to address topics related to STEM students; they involve meeting STEM faculty and community leaders as well as attending socials and family dinners. These meetings are 
a combination of social, professional, and academic skill development. The three sessions I observed were STEM support focused, professional development related, and social support oriented.

\section{Session 1: STEM community development. The STEM community development} meeting was a program designed for students in LSAMP to discuss their feelings about being persons of color in a STEM discipline at a Historically White Institution. It happened towards the beginning of the semester. A combination of first and second year students attended; most attendees were women. The meeting started with students getting reacquainted in the large group setting. Students shared their feelings about upcoming tests. This was a positive experience as many learned they were taking the same classes but at different times. Overall, the environment was positive and supportive.

Next, the graduate assistant conducted an icebreaker. This activity required students to choose between two sides. They utilized the room to differentiate sides. Some of the choices were: morning or night person, physical planner or electronic, top bunk or bottom bunk, etc. These conversations were lighthearted, full of personal stories, and laughter. The icebreaker led into a discussion about tests and preparation for the first tests of the semester.

The conversation segued into a video presentation about an African American STEM student's experience during his first semester of college. Students were engaged in the video; some leaning forward while listening to his story. After the video, the graduate assistant prompted the students to share their reactions to the video clip. The conversation naturally moved into the topic of the difficulty that comes with being a STEM student. Some of the concerns expressed were if they were smart enough to take hard classes in STEM, the length of time it takes to comprehend, and if they were going to be competitive based on their credentials. 
On the positive side, students shared their success stories of good relationships with professors, putting in the extra work, and finding success. There was an equal amount of support when students discussed their challenges and successes, which could be seen through head nods and sighs of agreement when students expressed frustration as well as applause when students shared their successes. The environment was conducive for authentic sharing and feedback. The graduate assistant asked students to reflect on the video clip where the student spoke about being the only person of color in their class. The students in the meeting all identified with this as their truth.

Some students even spoke about feeling they were not smart enough in the classes where they were the only person of color, which also led to feelings of isolation and comparison to their white counterparts' prior knowledge. The graduate assistant led a discussion on how students can overcome those feelings by talking about elements of resilience in their lives and personal mission. Many students reflected upon places of resilience in their lives in light of challenges and difficult circumstances. More than one student voiced these concerns while other students shared where and how they were resilient in difficult circumstances.

The final part of the discussion challenged the students to think about their purpose and mission for being in school and the influence of their mission in the decisions to continue. Some of the students' missions were: to make their families proud, to be the first in their families to graduate, to attend graduate school, to start a business, and to serve their local communities. The essence of this first meeting showed the students can utilize LSAMP to normalize their experiences, to encourage one another, to be challenged by the staff of LSAMP to rethink their challenges, to refocus on their missions and purposes for being in school, and to utilize one another for support inside and outside of the classroom. 
Session 2: Professional development. The professional development session provided students with an opportunity to hear from peers who pursued internships and research opportunities. The panel was comprised of sophomores, juniors, and seniors who applied for faculty mentorship, research opportunities, or internships. The topics included in their discussion were time management when amidst professional development opportunities, networking, utilizing the resources in LSAMP, maintaining grades, and asking for letters of recommendation.

Another component of the event was a faculty mentor and mentee pairing from the Biology department. LSAMP pairs students and supportive faculty members for the purpose of strengthening the students' experience in STEM. The pair discussed the quality of their mentorship, the research they conducted together, the opportunities that have come for the student because of the mentorship, and the friendship they have developed over the course of the mentorship. The students who attended the meeting were freshmen through senior status. Students left with an understanding of the opportunities they have to advance and diversify their experiences beyond the classroom.

Session 3: Social gathering. The social gathering was a free flowing discussion with a catered Italian meal at the end of the semester, which meant students were thinking about finals and their upcoming winter break. A combination of first year, sophomores, and juniors attended. The majority of the students were sophomores who participated in LSAMP the year prior. They used the conversation to discuss study tips, frustrating subjects, classes in common, and stories about classes. The graduate assistant of the program led the group in a reflective discussion about highlights of the semester, most important lessons, and the advice they would give to a student of color entering college as a STEM major. 
The highlights from the semester were having opportunities to be social. The consensus was that coursework required many hours engaged in study and less social opportunities. Being able to relax and enjoy other facets of their college experience was rewarding. Other students talked about their recent connections to faculty mentors, research and job opportunities. Many of the students discussed not being confident in research and working in a lab prior to being a part of LSAMP. This topic brought up points of reflection of growth from the beginning of the semester. The major lesson discussed among the group was to take advantage of every opportunity. Students were clear that some things were passed over that were possibly valuable. One student shared that an extra credit opportunity would have been the difference between an A and a B. Finally, the advice given was for students to get to know their professors, find groups of people to study with, and stay connected to LSAMP. Much of what they expressed students needed was connection. Many felt LSAMP was a connector for them to research, jobs, peers, and faculty members.

This event was also a place for venting. One student said a couple times that she was having a difficult time in one of her STEM classes. Much of what she had to say was not positive; her peers asked questions and encouraged her. Eventually, it became clear that she was being hard on herself as she was earning a B in the class she lamented. The students were able to encourage her and help her to see that it was not as bad as she thought.

The end of the meeting was encouragement from the graduate assistant. The students were encouraged to continue networking. The graduate assistant closed the meeting by sharing personal information related to networking, preparation, and confidence building. The meeting ended with the graduate assistant providing words of encouragement, perseverance, and determination. 


\section{Interviews}

Qualitative research methods were chosen for this study for the purpose of capturing the unique experiences of first year African American students pursuing STEM majors.

The interviews took place on the campus in a small conference meeting space at the

midsize Midwest University. The conference space was chosen because of the intimate space and because it did not have windows, so it provided privacy and confidentiality. Interviews were conducted at the close of their first semester in college. Two of the participants agreed to join the study; however, they returned to their hometowns for winter vacation. One interview was conducted via video conference and the other was conducted over the phone. To reduce risk of a breach of confidentiality, participants chose pseudonyms at the beginning of their interview. One student opted to use his name; however, I created a pseudonym for him to maintain total confidentiality. The pseudonyms were used throughout the interview, throughout the transcripts, and throughout the entirety of this work. The hour-long interview included eight questions that asked students to discuss their experiences prior to college, first semester experiences, and their ideas surrounding smartness and identity.

After data collection was completed, the interviews were transcribed within days of the initial interview dates. Although the initial interview allowed for immediate connections to the literature, the interviews were collected and analyzed with the understanding that "data are partial, incomplete, and always in a process of re-telling and re-membering” (Jackson \& Mazzei, 2012, p. ix). Considering this, the method of data analysis required the theoretical framework to drive the process. Depending solely on the researcher to transcribe, code, and create themes is a partial process and leaves room for holes and partial understanding of the data (Jackson and Mazzei, 2012). 
The use of Critical Race Theory situated race and racism at the center of the discussion to understand the students and their schooling experiences. However, in terms of coding and themes, critical discourse analysis challenged the researcher to review, categorize, and make meaning of the data looking at the use of language (Gee, 2011). In particular, critical discourse analysis looks at not only what is said but also what is being done. Not only did I want to know what student experiences were like through the lens of Critical Race Theory, but I needed to know how or if those experiences impacted their personal views on identity. Gee's (2004) work notes that discourse analysis becomes "critical" when the goal is to address a social issue and underlying issues not explicitly addressed. The expectation entering the study was for students to be able to identify their experiences in school; it was not clear that they would be able to identify them with racism at the center of their reflections. CRT is useful in this way.

On the other hand, Luke (1995) suggests that "discourse analysis can be used to address broader sociological concerns about the construction of power and identity and the distribution of symbolic and material resources" (p.37). In the case of Hatt (2012), Figured Worlds was used to understand the artifacts and symbols (structural) used to categorize students into systems of hierarchy and dominance. In this current study, the symbols of grades and standardized testing were used as a means of positioning students. In CRT, racism is permanent and ubiquitous within society and, in particular, the system of education. Critical Race Theory used as the framework revealed multiple themes that I have titled sources of significance. These sources speak to similar artifacts, symbols, and meaning making tools that cause for students to be positioned and dominated. By using critical discourse analysis, the language used to express students' experiences was analyzed to see how they made meaning of some of the structural issues that impacted their educational experience. Much of the work that has been done to 
explain this work through Critical Race Theory is found in chapter four. The following chapter allows for the work of critical discourse analysis as the students share how they have made meaning of who they are based on their educational experiences.

The work of understanding how identity and discourse are interconnected through this type of critical lens necessary for understanding the complexities of student experiences. Macro level structures exist that students must interact with on a daily basis. The question that I sought to answer was how students reproduce these structures. Or, do they resist these structures? Critical discourse analysis was used to understand where students were related to how they saw their position based on the structural issues present in their schooling experiences. With the good work of Murrell (2007), there is an expectation that some students will resist by using their own agency to push back on institutional racism. Chapter five helps to locate not only what has happened to the students, but how they have responded. In Critical Race Theory, it is known that one cannot be colorblind or neutral to race.

By using the literature of the history of assaults within the educational system, I expected to find structural issues in the student's experiences. I expected some students to have been subjected to a series of racist practices in nature, whether knowingly or unknowingly. Critical discourse analysis sheds light on how students have interpreted these practices related to their identity. Critical Race Theory allows space for this to happen as the lived experiences of students are considered a valuable, necessary part of the research agenda.

Critical Race Theory is utilized as a means to look deeper into ways race and racism shape students' academic identities and discourse about their academic achievement and/or struggles, specifically in STEM. In particular, the tenets that CRT speaks to are: the prevalence and permanence of racism, whiteness as a property, colorblindness, interest convergence, and 
counterstories (DeCuir \& Dixson, 2004). The core of this work has relied on the use of counterstorytelling as a means to understand the experiences of first year African American STEM students.

CRT as a framework and tool of analysis is paramount for this study because of the need to look at the way systemic, historical, and racial issues plague the way in which the education system is structured (DeCuir \& Dixson, 2004). Even more, participants of this study may not readily say or see the meaning behind their experiences. They may not connect with the historical references of eugenics and deficit language. Therefore, using critical discourse analysis is the most fitting way to make meaning of the data, both through participants' autobiographies and follow-up interviews (DeCuir \& Dixson, 2004).

To ensure trustworthiness and validity, all students were invited to share in the research process by viewing and verifying the accuracy of their transcript. One student responded to the request and validated the story as interpreted in the research study. Merriam (2009) notes the importance of member checking, where participants have the opportunity to review completed transcripts and the interpretation of the work. During the interviews, I consistently paraphrased student statements with the help of their confirmation and, at times, correction. In addition, this study used three points of data collection: autobiographies, observations, and interviews. Lincoln \& Guba (1985) note that qualitative researchers must ensure that their work is credible, transferable, dependable, and confirmable. This study employed in person/interview member checking, post interview member checking, and triangulation through three points of data collection. 


\section{Chapter Summary}

The assault on the African American heart and mind has been a systematic process through White supremacist practices that include slavery, eugenics, segregation, Jim Crow laws, school tracking, standards based testing, deficit theory, and unequal school funding (Anderson, 1988; hooks, 2003; Valencia, 2012, Reddy, 2007; Ladson-Billings, 2006 ). The influence of these practices on the educational system are not without consequences as the victims who have experienced the brunt of the pain associated with these practices have been deemed the perpetrators and antecedents for the calamity that has befallen them (Valencia, 2012; LadsonBillings, 2006).

Present-day deficit language, including terms like "at-risk," culturally deprived and disadvantaged, sounds identical to the language used to dominate enslaved Americans by excluding them from the educational process (Anderson, 1988; hooks, 2003; Woodson, 1933, Dubois, 1968). The language also resembles that of the eugenics movement that considered nonwhite members of society intellectually inferior (Reddy, 2007; Valencia 2012). African American students in the $21^{\text {st }}$ century are still plagued with the same White supremacist ideology that seeks to dominate them and keep them in positions of inferiority (Reddy, 2007; Valencia; 2012; hooks, 2003).

After a number of years of educational training in a system with a dark legacy, it is important to learn how these practices manifest in the minds of first year African American students. Many current educational practices are exclusionary and have impacted generations of African American students. Some of which include unequal funding laws (Kozol, 2005), biased educational tracking (Blanchett, 2006), and lack of access to Advance Placement courses 
(Roderick, Nagoaka, \& Coca, 2009; Nasir, McLaughlin, \& Jones, 2009; Darling-Hammond, 2010).

These practices impact African American students studying science, technology, engineering and math (STEM) in even greater ways. The language, ideology, and stereotypes closely tied to these majors/fields are steeped in white supremacy and are hegemonic earmarks for white men (Berry, 2008). The gatekeepers for these fields begin putting up barriers for the youngest of African Americans (Berry, 2008). Those who are able to press past these barriers are considered capable of playing the smartness game; however, those who are not able to jump through the created hoops and barriers are labeled as incapable and deficient (Hatt, 2016). The argument is that smartness in steeped in whiteness and Eurocentric values. Ways of knowing, behaving, and understanding that are not within the confines of whiteness are excluded as invaluable and invalid (Hoff, 2016; Hatt, 2012; 2016). Therefore, access, opportunities, and the curriculum needed to be successful in STEM can easily be blocked by the teacher perspectives on who they deem can or cannot be smart in STEM (Berry, 2008). The hearts and minds of first year African American students are at risk of believing the ideologies cloaked in racism, which have gone unchecked in policies, educational reform, and teacher biases.

It is befitting to close this chapter with a review of the opening story about Kimberly. Kimberly's story is one that speaks directly to teachers projecting their biases onto Kimberly and her African American peers. The notion that the students were not able to take the AP exam because "no one in their school passes the exam" taught the students that they had intellectual limitations. Dweck's (2006) work would clearly state that these students were set up to believe that they had a limited capacity in their academic abilities. Instead of being challenging in advanced work, they were reduced to believe they were mediocre, average, or even below 
average. Critical Race Theory exposes how the teachers perceive the intellectual ability based on the student's race as well as the teachers' racial biases (Ladson-Billings \& Tate, 2006). Kimberly noted that another teacher said when students in the school entered college, they need to be aware that the white students would know more than they did. While racial undertones are present in the AP test scenario, blatant racism is in the second scenario that requires attention to the roots of the social construction of race, whiteness as a property, and the permanence of race in the education system (Ladson-Billings \& Tate, 2006).

Applying critical discourse analysis allows Kimberly's story allows for the hidden and unspoken to be uncovered and voiced. The next chapter allows seven STEM African American students to tell their stories and be heard in a way that uncovers the truth about the messages that have been projected onto them. 


\section{CHAPTER IV: SCHOOL EXPERIENCES}

\section{Introduction}

The seven participants of this study are from diverse school systems, varying suburbs, and cities and are pursuing different major paths in STEM. Each student's story is unique and captures dynamic experiences that influence their individual identities. The goal of this chapter is

to share the lived school experiences of first year African American STEM students and how these experiences shaped beliefs about self and their intellect. This chapter also explores the interconnections of hegemonic practices, student experiences, and academic identities.

Moreover, this chapter answers two of the four research questions set for this study. These questions are indicated below:

1) How do African American STEM students reflect and describe their high school experiences?

2) In what ways did African American students' schools and educators contribute to their self-perceptions about their intellectual abilities?

The remaining research questions are answered in the forthcoming chapter.

\section{Narratives Matter}

It is important to recall that a narrative has been constructed that speaks to who can achieve in STEM, which simultaneously promotes a message of inferiority for African American people (Berry, 2008). This narrative is also about power and domination for one group and suppression and marginalization for an already oppressed, marginalized people (Solórzano and Yosso, 2002; Stanley, 2007). CRT calls on scholars to amplify the voices of those who have been silenced and whose realities often go hidden and untold ( $\mathrm{Su}, 2007)$. The findings from this study show, whether aware or unaware, that students have been positioned in the middle of a 
narrative of dominance and marginalization. Some of the students are trying to create their own narrative and defy the messages of inferiority while others are unaware that they are in the middle of a storyline constructed for them.

Whether students reflected positively, negatively, or indifferently on their high school experiences, they identified four primary sources of significance. These sources revolved around teachers, access to curriculum, tracking, and standardized testing. In the remaining parts of this chapter, what mattered to students in their high school experiences is shared through their voices and considered in the light and spirit of Critical Race Theory.

\section{Teachers Matter}

\section{Bias and Expectations}

The impact and influence of teachers extend beyond the isolated classroom experience. Teacher expectations, biases, and belief have the ability to have strong consequences in the lives and identities of students (Oakes, 1985; Dixson \& Rousseau, 2006, Dweck, 2006). Low standards, lack of care and concern, and negative labels can be critical influences on students and their identity. Conversely, the opposite can be said about student identity development when a teacher cares for and has high expectations for students (Oakes, 1985; Dweck, 2006; Rist, 1970). Study participants Cece and Jamiya speak negatively about the expectations and beliefs that teachers had of them. Both of their reflections of high school required further reflection of their formative years of education, particularly experiences in kindergarten through eighth grade. For instance, Jamiya speaks to the challenges of entering the elementary school where her older brother and sister attended.

It didn't feel like my teachers like they believed in me as much as my high school teachers did. 'Cause some of my teachers were like my brother's and sister's teachers. Like my sister's like seven years older than me so like they taught her everything and she didn't really try in school either. So I guess what they saw in her they saw in me too. 
Jamiya speaks about her K-8 experience as a prolonged nightmare. She notes that she was negatively labeled by her teachers before she had a chance to develop her identity in school. The biases of her teachers impacted how she experienced school (Milford \& Tippett, 2013). Jamiya explains her sister dropped out of school after $8^{\text {th }}$ grade. The last school her sister attended was the first Jamiya would attend.

...her teachers were my teachers... So then it was like they all just thought I was the same way as her. It was like they um...I felt like they weren't trying to put no effort in to 'cause they dealt with my sister and my big brother. And, it was like if they're not trying to do anything you must not be trying to do anything either.

Cece also discusses her high school experiences with the reflection of her kindergarten through eighth grade years. Cece's story includes a move from a large metropolitan city, where the students from her school were majority African American, to a school in a suburb that she refers to as "rich, wealthy, and white." She considers this time of transition hard because of the culture shock of being at a majority white school. There was also the additional shock of an overabundance of resources and extracurricular activities, a stark difference from her private urban school, which she only recalled an afterschool program used primarily as a holding place rather than a program of engagement.

Research suggests that suburban school districts can spend between $\$ 4,000$ and $\$ 9,000$ more per student than urban and minority schools (Kozol, 1991; Kozol, 2005). Schools that serve primarily students of color in urban districts are left with fewer resources and opportunities for students. CRT scholars argue that, at the core, this reality is racist and exhibits whiteness as property, where whites are and feel entitled to have the best of everything, including the right to better education (Ladson-Billings \& Tate, 2006). 
During the reflection of this move, Cece receives clarity about her private school, the teachers, and their beliefs and expectations of her.

Umm... 'cause I thought I was good from my private school in $8^{\text {th }}$ grade. They considered me one of the smartest ones but they didn't really teach us a lot, now that I'm looking back on it. And, I guess they had different standards at the public schools at [suburb].

Later, she discusses the reason in the difference between the schools.

It was just some of the things I've never heard of before. Like I thought I was good, but then... they threw all this different stuff at us. And, it was a different workload than I was used to. It wasn't much really expected of me. Um...in eighth grade.

It is not clear the depth to which Cece reflected prior to this opportunity to tell her story; however, during her sharing, she was saddened by the reality that the expectations of her at her previous school were so low. Cece acknowledges that she was one of the best students in her previous school; she earned the best grades and did exactly what was required; however, it was not until she was exposed to another school that she realized she was not receiving the same kind of education. From the outdated books to the uncertified history teachers teaching math, Cece started to realize the serious issues at her private school. Cece's experience resembles the days of segregation where African American schools were taught in schools with second hand buses and books as well as underfunded, dilapidated facilities (Morris \& Morris, 2002). There are clear similarities in the "separate but equal" school setting for African American students and the experience Cece speaks of in the $21^{\text {st }}$ century.

In her reflection of the teachers, Cece notes that the teachers were not exactly the kind excited about teaching and learning.

It wasn't really as inspiring or motivation. It was just like "your parents are paying us [for you] to go here and keep you out of the public schools. Like we are going to go to mass or whatever."

This is important to note because the kind of education Cece received caused her to change her behavior in school and perspective on school. 
To me, it was easy. I actually had this phase in seventh grade when I wouldn't do any...I would do my work but I would just slack off and kind of dumb myself down for the other kids around me. I remember this one boy said to me... he was like "why do you talk white." And, I never heard that before until I came to that school. From the different private school, this last one, he was like "wow, you talk white." Are you like white? I'm like no! I'm like "we're all black." So I didn't understand. So once I realized what level they were on, I kind of dumbed myself down. Then I had this phase in eighth grade when I kind of picked it up.

Generally, the kind of education that and her peers received would be analyzed through the students' inadequacies evidenced in the closing the achievement gap discourse while underlying issues related to opportunity are under analyzed (Nasir et al., 2009; Thompson, 2002; Darling-Hammond, 2007; Finkel, 2010). This is no different from Cece's original assessment. Experiencing lack of motivation amidst outdated books, low expectations for her, an uncertified math teacher, and low rigor curriculum, Cece did not consider the possibility that her peers could have lost motivation in the midst of the same conditions. CRT would argue that researchers must pay close attention to the underlying issues, which include lack of academic rigor, high suspension rates, underfunding, low touch administration, poor instruction methods, lack of college preparation guidance, and expectations of failure with their schools (Nasir et al., 2009; Thompson, 2002; Darling-Hammond, 2007; Finkel, 2010). All of these issues impact how students experience school.

After challenging Cece to consider her experience alongside the experience that her peers had, she later acknowledged the students may not have known something was wrong with the kind of education they received. Woodson (1933) refers to two distinct educational outcomes for whites and African Americans, in that whites are supported, strengthened, and encouraged through stories told and retold about their superiority while African American people are perpetually labeled as inferior and unable to meet educational standards. Cece's discouragement in the seventh grade very well could have been the sentiments of her peers at earlier times in 
their journey at that school. With low expectations disrupting Cece's motivation, one of the highest achieving students at the school, it cannot be ignored that other students could have felt the same dissatisfaction under the same conditions.

The impact of low teacher expectations and negative teacher labels impacted both Cece and Jamiya. Although Cece lost interest in school in seventh grade, she was able to motivate herself and refocus her attention on her studies. The desire to refocus on doing her best work came from her desire to pursue a medical degree in the future. This goal jarred Cece from her discouragement. Jamiya, on the other hand, was labeled before she could show interest in school. She believes she took on the persona the teacher prescribed. When she moved to high school, Jamiya had a major change in her interest in school, which was directly connected with her new teachers.

Like in grammar school I was always playing, not paying...focusing in class...I wasn't taking school serious. But when I got into high school...I actually liked going to school. I liked learning because my teachers were awesome. And like, I was actually learning things and getting it. And it was something new for me because the lightbulb was on. Jamiya's account of her desire to learn and confidence in her abilities being restored are directly linked to the power of an awesome teacher. According to Kane (2012), teachers have to know that there is more to the classroom than just learning the content; students are learning who they are or are not in the classroom. In the case of Jamiya, her outlook about who she could be as a student changed based on a different set of teachers in a different classroom setting.

\section{Teaching Beyond the Classroom}

Jamiya's teachers were not only awesome because of their ability to jumpstart her excitement for learning, she further explains that her teachers were more than just teachers.

My biology teacher, Mrs. Thomas and my chemistry teacher Mrs. Davis. They were totally amazing. They weren't just there for me like for school purposes...like academic reasons. I could come to them with any problems I had at home or anything. They were 
just there to listen to me and I could 1 like trust them with anything. I had somebody there who was like encouraging me in all parts of my life.

Jamiya's outlook in school completely changed upon entering high school. She attributes this to good teachers who were interested in her success as a student and had genuine concern for her as whole person. High school was a saving grace for her as she was able to connect school with a safe place to learn and grow. She admits that she felt bullied by her teachers in grammar school. The teachers were on guard to catch Jamiya not behaving in a way that was appropriate to them. Jamiya believes she was being picked on by her teachers in grammar school. She discusses the stark difference between her grammar school and high school teachers. When she moved to high school, Jamiya's belief in herself was predicated by the teachers who believed she could succeed in school and have a successful life. One of the main reasons she believes she could succeed is because her teachers told her on a regular basis that they believed in her. Jamiya shares her account of how she knew her teachers believed in her.

They said it a lot because my school was dedicated to caring for the students. But um, I just felt it by the way that they treated me from how I was being treated in grammar school...to how I was being treated in high school. It was just like there's actually some good teachers out there and they actually want you to succeed in life. So it's like this is how I'm going to be successful when I have teachers like that.

Interactions with teachers, their words of affirmations, and care beyond the classroom made going to school worthwhile for Jamiya and helped her to believe in herself as a student. In fact, her love of learning and excitement for STEM were sparked. Jamiya speaks about the fact that she doubted herself in grammar school and believed that she was unable to succeed in math and science. However, when she moved to high school, her doubts about her skills and intellect subsided.

Once I got into high school I didn't. Because like, I was doing so well in my math and science classes that I was like I could actually do something with this. Especially because I enjoyed it...and I had teachers who were actually teaching me something. So, I felt 
like...I can do this. But in grammar I had no doubt that I wouldn't even be making it to high school.

Like Jamiya, Miracle's teacher's care made a difference in her life. In particular, her teacher extended himself beyond classroom hours to encourage her during some difficult times in her life.

I lost a lot of people in high school, like I lost my father, my grandma, my auntie, granddaddy, yeah that's about it. But it was all of them close to me. So it was like back to back to back to back. My grandma was sick going through cancer. I was a sophomore in high school. So like most of the days I wouldn't go to school because I was staying at home helping my grandma.

Right after the loss of her grandmother, Miracle's father was suddenly killed. In this moment, she did not want to return to school; however, the care of Miracle's teacher helped her think through the decision.

But I was just like...the days that I could miss school I was like forget it. Forget it! um... it got to the point that my advisor would call the house like Miracle come to school today *** laughter. I was like naw... I'm okay. My grades started slipping though. And, I'm... a lot of people...my teachers they seen potential in me....And, um he was....the teacher, Mr. Christian, he came... he would come to my house when my daddy died like are you okay? Are you good? You need anything? What teacher does that? You're a teacher! Stay at school, like.

Miracle speaks about the struggle with staying and finishing high school because of some of the personal difficulties that threatened to impact the completion of her education. A caring teacher who moved beyond classroom responsibilities helped Miracle in sensitive and critical time. Murrell (2001) suggests that successful teachers in urban school settings are considered “community teachers." These teachers "draw on a richly contextualized knowledge of culture, community, and identity in their professional work with children and families in diverse urban communities" (p.4). They are not solely concerned about what is happening within the class, but 
they care about the entire make up of the student's experience. Miracle can attest that the kind commitment to teaching beyond the classroom was a powerful tool in her life.

\section{Inspiration by Pedagogy}

In addition to the beyond the class, students in this study were clear on the kind of teaching that made them enjoy STEM. Bruce's experience in his AP Biology class proved to be impactful because his teacher made the subject come alive.

Um, Mrs. Peterson. My AP biology teacher. She was like really awesome. She was a funny, she really engaged the class with what we were learning. Uh, and like uh like...well...it's really hard to explain this. I feel like she taught me more than what I learned in Biology class this semester. I just remember more of what she taught than what I learned here.

Bruce's excitement about STEM directly correlated with his course and the way the teacher engaged the class. This was also the case for Cece as she attributes a great part of her interest in STEM to her high school physics and anatomy teachers.

I took physics and anatomy and liked them both. They were really cool classes. My physics teacher, he would make pancakes for us in class. He was a part time deejay and so he would deejay in our class and have like strobe lights. And, we would watch a lot of cool physics YouTube videos of like people blowing stuff up....and we built our own cars and had our own like velocity experiments. That was nice, but I enjoyed anatomy more because we had a lot of field trips. We went to an open-heart surgery cadaver lab. We just did so many fun things.

Leticia also spoke of her physics teacher who peaked her interest in STEM.

He taught us Physics and Astronomy and that made me like really like just science in general cause I was like this is amazing-I love it. That made me get into science even more...like I just steered towards animals cause I just love animals anyway so that was just going to be perfect.

Jamiya also credits her excitement in STEM to having engaging classroom experiences

with teachers in high school.

Yeah, like after freshman year we dissected a pig......after that I was set on doing something dealing with medicine and science. Like that is what I want to do, so I became teacher...quote, unquote teacher's pet. With all of my science teachers it was just so 
interesting to me. And, like even my math teacher...I loved them too 'cause I was always doing well in their classes...cause they was making stuff enjoyable.

Miracle mentions that she attended a school that taught students how to be socially conscious about issues of inequity. A large part of why she chose to go into pharmacy was because of the kind of education she received. She was inspired by learning about the social and racial equities and was challenged not only to care about her community, but also to be a change agent. She speaks of her experience taking a cultural studies class that motivated her to pursue her career path.

He taught us about gender, race, equality... all that stuff. I just feel like after reading so much stuff, you know talking about it, discussing it...I feel like it's not enough African American women that's doing more important stuff. I feel like it's not enough women in the medical field...But then, its not just about getting in the medical field, like the bigger goal you're trying to accomplish and my teacher always told me when learning stuff about gender and race and all that stuff, you see ... of course you see all the bad stuff like at the end it's like what can you to do kind of sort of change that. And, I kind of sort of want to change that. By changing it I want to live in the shoes of actually being...doing pharmaceutical work.

Miracle's experience in the class taught her to expect injustice but not to be afraid of her power and voice. Although she expects to encounter racism in the field she is pursuing, she welcomes it because her bigger desire is to create change.

I see a issue... I want to change a issue. But, how am I going to change the issue. And, that's the type of mentality that the class kind of taught me. You see something... you notice it. You don't like it...change it... Change it how? In an effective way.

Ladson-Billings (1995) argues that in order for good teaching to happen, "students must experience academic success; students must develop and/or maintain cultural competence; and students must develop a critical consciousness through which they challenge the status quo of the current social order" (p.160). These were present in the case of Miracle and deeply enriched her educational experience. 
This section depicts the power of teachers in the academic lives of these students. In the case of Cece, low teacher expectations impacted her desire to stay focused in her academics. For Jamiya, teacher bias and negative labels stood in the way of her exploring her desire to pursue STEM. However, her account about the care she received from her high school science teachers proved to be pivotal for her success in school and STEM. In a similar way, Miracle experienced care beyond the class that helped her continue to pursue school and STEM as well as culturally relevant teaching pedagogy. Moreover, it is clear to see the power of inspiration in the lives of Bruce, Leticia, Cece, and Jamiya.

\section{Tracking and Access to Quality Curriculum Matter}

It is well documented that African American students tend to be tracked in lower courses, leaving them susceptible to low expectations from teachers, subpar curriculum, and higher rates of drop out (Oakes, 1985; Ansalone, 2010; Werblow, Urick, \& Duesbery, 2013 Mickelson \& Everett, 2008). This reality is no different for some of the students in this study. Even as early as a kindergartener, Jamiya was well aware of being tracked. She explains the two distinct experiences students had----based on the "said" intellect of students.

Yeah, there was like two groups...the smart group and then the dumb group. And that's how everybody was classified. And, the teacher she was actually nice and caring if you were in the smart group. But like I was somewhere in between the middle but more so on to the dumb group, so it's like she wasn't really trying to be bothered with you...they cut up our classes and that's how they ended up separating us.

This separation meant that some students were going to be successful in school and their

futures. A student tracked into lower courses is likely to take on the identity of the track they are placed into, which has an impact on their self-concept as learners (Ansalone \& Biafora, 2004).

The indicator of success in her elementary school hinged on one thing, a standardized test score.

Cause like we took this standardized testing and if you scored really high they put you in this one class with the awesome teacher. And, everybody wanted to be with that awesome 
teacher. But, you scored low you would never ever see that teacher. And, then you never saw your friends again. When we had the budget cut where we had to like send half of our teachers away, and they ended up sending all of the good ones away... so then all the smart kids got stuck in the same class as the dumb kids. That's only reason why we ended up like figuring things out.

Not only was a budget cut the way that Jamiya learned about the difference in experiences in the dumb and the smart classes, she also had personal experiences testing into both the smart class and the dumb class.

I made it to the smart class like once and then, after having...cause you have to take the test like 3-4 times a year. Like after doing real bad off one of the tests like they sent me to the other group. That's when I was like "oh okay, I see how different it is." Cause even the pace was slow.

CRT argues that the legacy of white supremacy and eugenics, both steeped in racism and social construction of race, manifests presently in countless ways, specifically in harmful tracking policies (Solorzano \& Ornelas, 2004). Cece shared the account of her transition from her private school to the public school. She noted that her transition was difficult because she felt she was behind. The students who went to her new public school appeared to know more than her. Another reason she felt behind was based on how she was tracked when she arrived to her new school.

Because um...what happened was I took a test in eighth grade um and we had like our one thing going at the private school. I don't remember which exam it was... but it was kind of like for high school placement. And, when we moved and registration um...it was time to register for classes or whatever. They said that my test scores were not equivalent to what the standard was. So they placed me in academic when I feel like I should be in like honors. But, apparently, then I said...well okay, I must not be as smart as I think I am. So I was placed in regular classes and I ended up doing bad in those classes. And, I just felt like everybody knew so much more around me. And this is only ninth grade. Which is really sad. 
Cece experienced the legacy of standards based testing and school tracking, which link not only to social policies and pseudo-science but also to white supremacy ideology (Valencia, 2012; Reddy, 2007). Cece was confronted with not being on the same level as her Caucasian peers because of her test scores, so her test scores dictated what classes she could and could not take. For Cece, this meant that she was in a position to question everything about her intellect. To CRT, it speaks to the racial marginalization in education that stems from an often untold era of American history that includes the strategic plan to systematically eradicate racially, mentally, and physically "defective" humans (Valencia, 2012; Reddy, 2007; Osgood, 2010).

The eugenics movement, grounded in white supremacy ideology, labeled and positioned nonwhite persons as intellectually inferior (Gould, 1981). America's love affair with standardized testing comes from a harsh, cruel era where various fragmented tests and measurements were constructed in order to build a case to substantiate this pseudoscience (Gould, 1981; Valencia, 1997; Reddy, 2007). The birth of the standardize test began with IQ testing in order to track students into their said predestined futures (Reddy, 2007). The history of giving power to a single test score as a sole indicator of intelligence is racist at the core because it was created during the era of and with the agenda of white supremacy.

At the core, these structural issues have been embedded in the fabric of the educational system. Whether Cece knew about the legacy of racism connected to her educational experience in school, she still could not bypass the impact of this truth. For Cece, her identity in school was challenged as she was met with exclusion to classes. Later, Cece tells how she determined that she was not going to accept that a test score was going to keep her from her classes. She uses her agency to push back against a system prepared to exclude her from a rich educational experience (Murrell, 2007) 
I want to do something medical so like AP Biology is my best option. So, what I had to do was talk to the head of the science department and fill out a form. Because like I said with the test scores, they put me in regular so in order to get in honors and Advance Placement, you have to like show your grades and you have to write you want to be put in a higher level. And, once you get put in that level you can't drop out until the next semester.

After following the procedures, Cece met with the chair of the science department, who waved her into the AP Biology class. Her determination was worth her efforts because she had great success in the course as it was one of the most exciting classes. In the midst of her exciting class and doing well in the course, she ran into another roadblock. She decided not to take the AP exam for college credit for fear that it would be too hard, and she would not pass it. Cece started doubting herself in the same way that she doubted herself when she was not allowed to take AP courses.

Um...biology was way harder. It was college level and she modeled the test in our class after what the exam was going to be like and I did good on some but I didn't feel like I would do well enough to get a 4 or a 5 . I would probably get a 3 on it. I mean, some colleges accept that. I think a lot would be like "ohkay you got a three on it" so I thought I was going to do that. And, also with the money thing, I didn't want to waste my mama's money cause I knew she was gonna have to pay for it. I'm like, if I'm going to do bad on this, I don't think I wanna take it. Um, and now I actually taking it because I'm in Biology now. I'm in Biology 199.

Cece regrets letting this fear stand in her way because she is having much success in her class. She discusses her happiness with her decision to advocate to take the AP Biology course because it put her in the position to consider becoming a tutor at the university's tutoring center.

... I'm about to have an A because it's the same material that I was learning in high school. So like because I decided to take that step in high school, now I'm ahead in college and I was going to tutor in 199.

On the other hand, Jacob speaks of his experience where he moved from a school with many resources to a school with very few resources. He explains that his first high school had diversity in people, activities, and college preparation opportunities. He describes the students at his former school as daughters and sons of mathematicians and doctors. He also notes that these 
students had been exposed to rigorous curriculum since their early days as students. He compares them as more educated than he was. However, his family moved from that state to another and required him to adjust to a new school. He explains that his new school did not have the same resources and. in particular, advanced classes.

I got there senior year...they didn't have math courses... They didn't have pre-calculus let alone [advanced] Algebra.

What Jacob speaks of is common for African American students in the United States as many schools that serve African Americans do not have access to Algebra II, a staple in the courses necessary to prepare for college success (Department of Education, 2014). Jacob continues sharing that he did not take math his senior year though his college major was going to be physics engineering. His move to this school made him feel stuck and not readily prepared for college. In hindsight, Jacob feels disappointed in his semester because his transition to college was very difficult. He attributes the hard transition to the lack of advanced classes in high school. If his high school had the coursework, he believes that he would have had an easier transition into college. Department of Education (2016) confirms Jacob's experience as African American students do not have the opportunity to prepare adequately for college STEM courses because courses like physics and calculus are not offered in their schools.

Leticia also reflects on her experience at her college preparatory school. She notes the difficulty in her college chemistry class because of the lack of rigor in her high school chemistry class.

She gave us packets and we had to do stuff out of the book. Or try to teach it ourselves. I mean I got a good grade in the class. She was just really...she didn't teach us like balancing equations....like I did not learn that. Apparently some people from other high schools did learn that...like I did not learn that----like at all. Didn't learn balancing anything...(laughs). 
She describes a conversation she had with college friends who also attended the same

high school.

...but like they said that my school was a college prep school. I don't know where they got that from...like, no it's not. It's not at all. And, it's like some other people from my school that goes to [college]... and they said we was not prepared for this...I said I agree... we was not...not at all.

Finally, Malik shares that he was clear that he expected his transition to college to be difficult because of the warning he received from his mother while in high school. He learned in his first semester the accuracy of his mother words.

Okay, so I went to a African American public school...no not public school, private school. Private catholic school. However, my mom felt that the education was not up to par with my counterparts. She thought that they were coming from nicer neighborhoods with nicer education systems. Meaning they learned more. And, then my school didn't take education as serious as they could have. Like, yes, [large metropolitan city] education, public system is like right here and mine was a little higher. But it wasn't where it needed to be coming to [current university], which is a PWI. So, she didn't feel like I was prepared. My work ethic would eventually let me catch myself up. And, then she suggested that I take developmental Chem class before I took Chem 152, so then I could be caught up. But I'm like that would set me back a semester that I don't have time for. I don't have time to be....so that's why I'm in this class. That's why I was in that class struggling because- I didn't learn what I needed to, to have the tools necessary to be ready. Like the first exam was review for everybody else. But I'm like WHAT, I didn't learn any of this.

Leticia, Malcolm, and Jacob each had experiences in their high school with their curriculum that made the transition from high school to college, and more particularly their STEM courses, a very difficult one. Conversely, Cece and Bruce experienced a smoother ease into Biology because their high schools had the same curriculum. It is important to note that Leticia, Malcolm, and Jacob attended predominantly African American high schools while Cece and Bruce attended predominantly white high schools. 


\section{Chapter Summary}

Students in this study reflect and describe their high school experiences as either helping or hindering their transition to college. For some, they could look to their teachers to be supportive, believe in them, and provide opportunities of engagement. For others, they experienced the opposite; these experiences directly impacted the way they saw themselves as learners. The same can be said for students with access to Advance Placement curriculum or a curriculum that prepared them for the kind of rigor they would experience in college. For those who did not have access to this kind of curriculum, the transition from high school to their first semester as a STEM student was difficult.

The voices of the students in this study are paramount in helping to confirm the position of Critical Race Theory that race and racism are central parts of the educational experiences for students of color. The stories reveal that students in this study who attend predominantly white schools had a better chance of engaging, quality teachers. It is also true that students in this study who attended predominantly white schools also had access to a quality curriculum that prepared them for the rigors of their STEM courses.

One of the tenets that CRT speaks to is whiteness being a property (Ladson-Billings \& Tate, 1995). CRT questions the racism behind African American students having to attend predominantly white schools to receive a quality education and quality teachers (Howard, 2008). For the African American students who do not have the opportunity to attend a predominantly white school, they find themselves relegated to subpar educational experiences. In turn, for the students who did not have the same access, they had concerns about their transition to college and in particular to their STEM curriculum. 
Although not always explicitly stated, in many cases the students in this study experienced conflict related to their academic identity. At some point, all of the students' intellect was questioned by virtue of a test, grades, bias or tracking. This dissonance in their academic identity cannot be assigned to the students alone. Their experiences exclaim that academic identities have to be examined in the light of educational experiences steeped in racist and discriminatory practices. 


\section{CHAPTER V: ACADEMIC IDENTITY}

\section{Introduction}

The previous chapter outlined how the educational experiences of the students revealed a difference in the way they experienced teachers, classes, and curriculum. The hegemonic schooling practices experienced by these students had an undeniable influence on their identities. This chapter explains the final source of significance for the students as an opportunity to segue into what I have termed the Academic Identity Continuum, a framework for understanding the identities of the students within this study. Prior to explaining the final source of significance and the continuum, academic identity and smartness will be revisited.

\section{Academic Identity and Smartness}

Academic identity has been defined as "the ways we come to understand ourselves within and in relation to the institution of schooling and how this identity shapes our own selfperceptions of efficacy, ability, and success in relation to academic potential, performance, and achievement" (Hatt, 2012, p 439). In the midst of this shaping, it is equally important to understand the agency and the necessity for students to have a choice in what they receive as truth related to their identity (Murrell, 2007). Some of the students in this study have been involuntarily tracked into the lowest courses, in some cases since entering the educational system. All of the students in this study have been inundated with implicit and explicit messages of their intellectual inferiority in some way.

Hatt (2012) argues that smartness is not about who an individual is, but rather who they have been assigned to be; schools are the places where students learn who they should and should not be. These assignments are intended to reify social status, racial hierarchy, and domination (Hoff, 2016; Hatt, 2012). Without resistance, students are positioned to consider the 
education they receive as paramount, vital, and neutral (Hoff, 2016). For the students who experienced school in an interrogatory manner, the kind of education they received requires resistance to ensure a false narrative about themselves is not taken as truth. African American students experience an academic world where they have been racialized and minoritized to the degree that a need to resist the pressure to become what the dominating discourse seeks to impose exists. Hoff (2016) notes history teaches that resistance against hegemonic practices has been commonplace for African Americans. In the same vein, withstanding an educational system steeped in racist and dominating practices without succumbing requires the same spirit of resistance. In the next section, the ways in which influence of grades, the final source of significance, has impacted the hearts and minds of the students of this study are highlighted.

\section{The Influence of Grades Matter}

\section{Early Impressions}

Grades had one of the greatest influences on students and their ideas and thoughts about their abilities. Some students in the study directly tie being smart to earning good grades. The foundation of smartness being connected to grades started fairly early for many of the students in this study. Whether through family members, teachers, or awards, grades carried a great deal of weight. Many students recall being rewarded very early in their lives because of good grades.

Families, teachers, and systems of awards situated students in the understanding that grades and smartness were synonymous. Cece describes the reasons she associated grades and smartness.

As a kid I definitely thought it meant to get good grades because that was praised a lot in my family. Like a lot of my family said stay in school go to college get a degree. And you know, make a ..be able to provide for yourself and your future family ... or whatever.. so just because they viewed education as the key, as the way out of poverty and stuff like that. Um I thought that I was smart being able to get good grades and kind of continue on in my education. But especially in grade school...like they would reward...like you'd get a sticker if you got a good grade on a test. They would reward that type of stuff. That's 
what I thought. It wasn't until I was older... a little bit older that I started to realize that you can be smart in different ways.

Cece's account of her introduction to smartness via grades showed multiple sources played a role in building this storyline. Over time, Cece's discovery of smartness outside of grades became a reality for her, but it also did not erase the pressure of using grades as a single determinant. Later in this chapter, it will be clear that Cece fights to resists this pressure.

Also, It was evident in the other students' descriptions of their early experiences that smartness and grades were tightly interwoven. For example, Miracle speaks about her vision of being smart as a child.

My vision of being smart when I was younger was good grades, all A's and B's...no C's no D's no F's. Yeah...nerdy type... a lame. All of that. But you were smart if you had your stuff together. It's people that's lame, wear glasses, um...I really don't have a definition of lame....not really popular. Don't really talk a lot. Um...the vision of a smart girl, glasses. Um, not a lot of friends...nerdy type.

Malcolm also remembers being honored as a small child because of his grades.

When I was a kid...it meant my report card had all A's. That was smart for me. I was on the honor roll. They always call my name for the little award ceremonies. Stuff like that. That was being smart for young Malcolm.

The early impressions of students in this study show that grades and school were paramount and had significant defining properties. For some, the definition of smartness still hinges solely on the earning of good grades. Others are in the middle of a tug a war to keep the power of grades from guiding their views of their intellect.

\section{Defined by Grades}

The results of this study revealed students were in a place where grades were the only pathway to smartness. Without stellar grades, students believed they were or felt dumb. In some cases, they made critical decisions based on these beliefs and feelings. For example, Bruce struggles to move past getting C's in STEM classes. Although he mentioned that he has not 
altered his study regime from high school much, he remains frustrated with himself as these methods are not enough to bolster his grades. Bruce does not feel he belongs in his major because of average grades; subsequently, the way Bruce views himself as a learner has been impacted negatively.

...it's kinda like I didn't feel smart enough cause like I ended this semester's Biology and Chemistry with a C. And, I got a C on AP Chemistry and AP Biology high school.

He also is concerned that other students earn higher grades than him. One of Bruce's reasons for changing majors from science to technology was based on not receiving the good grades he perceives his peers were receiving. The combination of comparing himself to others along with his grades and ACT scores made Bruce believe he did not measure up as a good student.

well, it's just like uh from all the people from like all the classmates that got the high grades and the high ACT scores, and got everything. Like, uh then I got the lower grades - so maybe I should try something else and maybe I'm not good enough for this subject...so, kind of encouraged the major change.

Bruce's account that his peers are smarter than him was not based on anecdotal information or confirmation. Bruce has a belief that has given an automatic assignment of smartness to his classmates, without knowing for certain their credentials. Bruce came to this conclusion because students appeared to have the higher grades and ACT scores.

I mean like I don't know their grades, but I know they did well..... I don't know....they just kind of look smart....

The look that Bruce referred to was an appearance of having a more engaged, enjoyable experience in the lecture. His picture of smartness did not include racial attributes, but rather character aspects like "nice and kind." Bruce was adamant that race had nothing to do with his assessment of his high school peers and college classmates being smarter than him. This belief 
was primarily due to members of his immediate family having advance degrees. Amidst his family members being educated, Bruce still argued that he was not smart because of grades and that his counterparts, who happened to be white, were smarter than him, earned higher grades and standardized test scores, without evidence to prove this.

Jacob also spoke about how grades impacted his first semester experience. He noted that the experience that made him feel like he did not belong was failing his first tests.

I failed three chemistry tests in a row. After that I started thinking is this really for me. Is this major for me? And, I started thinking about other things that I like...love to do.

The concept of loving to do something was connected to the idea of having a natural ability in a particular subject. Not having the perceived natural ability required caused Jacob to lose interest in his major. As his coursework became more complex and challenging and his grades were failing, Jacob found himself in a constant state of doubting his natural ability to perform in thesubject.

Many times. It's more of the complexity of the class in general. They say if you work hard enough at it then the reward will pay off. But I don't believe that. Because the thing you love to do should come naturally. Or that thing you love to do you would actually put all your entire effort into it. And engineering...I just doubt that I didn't put as much commitment in it as I thought it would be. I think that started to make me.... why.... why my interest in engineering went down.

Eventually, Jacob's commitment to his major waxed cold. Jacob also felt that he was in a position to appear smart by leading on that he was doing better in one of his STEM classes than he really was. After our interview, Jacob shared that he inflated his grades in our original interview because he was embarrassed and did not want to deal with the reality of the grades and what they meant. Jacob was in a position where he felt he needed to save face and manage any distress that might impact his psychological state (Robinson, Harris, \& Burton, 2015). For Jacob, grades inflation was part of his process to protect his smartness. Jacob's grades had so much 
meaning that he felt he needed to protect himself from others' perceived thoughts of him not being smart.

Not only did Jacob have an experience with grades that caused him to question his abilities, Malcolm had a similar experience where the amount of work he put into preparing for an exam did not yield the score he expected, which translated into him not feeling comfortable in his STEM classes.

Not at all. Not at all...because I felt dumb. And, I felt like oh my god, I felt like a failure. I even emailed my professor like I feel like a failure. Because, I really...okay so first...I was one of those college students that went in. I went to office hours, I had a tutor, I studied my butt off, and the first exam I got a 76. Mind you I wasn't used to getting exam scores like that. I'm used to ***laughter... A's, B's...majority A's because I work hard for what I want. So when I got a 76 I was really defeated. Like, oh my god Malcolm, why aren't you doing well. And, then that next exam it was even lower but I even worked harder and got lower. I was defeated. And, then it didn't help that my roommates were also in the same class, studied less than me but they were doing better than me every time.

Malcolm always believe the worst about his intelligence if he does not earn good grades because smartness for him can only be found within the structure of a school environment.

Yeah are like yeah I got street smarts. I'm good outside of school... And I'm like I don't know what that means...like how do you measure being smart outside of school. Cause you know---school is measureable. Outside... how do you measure that? You save money on gas. Like ... what makes you smart outside of school. I never know what it is therefore I cannot... I don't know if it's happening or not.

Malcolm's limited view of smartness is problematic because he is able to pinpoint the equity issues within schools that are predominantly African American and white. He explains that he recognizes the students in his high school did not receive the fundamental skills they needed to be prepared for high school. Malcolm initially viewed his high school counterparts as not being up to par in education. He felt that he was ahead of them in learning concepts because of his strong educational foundation in elementary school. However, Malcolm later saw the correlation 
between the students he considers not up to par and his college experience, where he realized the gaps in his high school learning experience.

I mean it could attribute to the fact that what they learned the year prior or just the fundamental building blocks that are necessary to grasp concepts easier like----um like I went to a elementary school where they - they did a really good job making sure I was up to par for my freshman year. So like I came into my freshman year knowing everything that they offered at my high school because my elementary school made sure we learned how to do A, B, C, and D. And, because the ...it's like prepared--- you know like elementary schools were to prepare you for high school, high school was to prepare you for college. My elementary school did a good job of doing that. But some people's elementary school did not. They were just in school playing or not learning what was necessary so they came into freshman year playing catch up and I feel like my high school didn't prepare me for college. So now I'm playing catch up. Or, catch up for my counterparts.

Early on in the study, Malcolm used school and grades as the sole barometer for smartness, but later, he assessed the ways in which his educational experience left him in what he considers dire straits in chemistry. He gave two explanations for his difficulty in chemistry. The first explanation was he is just not smart in chemistry. He penalized himself and categorized himself as dumb because he did not do well in a class. However, Malcolm recalled his mother's words about needing to prepare himself to work and study harder because of the gap left by the high school he attended. After this recollection, Malcolm was able to acknowledge that it was not him that was dumb, but he had a different quality of education than some of his college peers at what he calls a predominantly white institution.

Okay, so I went to a African American public school...no not public school, private school. Private catholic school. However, my mom felt that the education was not up to par with my counterparts. She thought that they were coming from nicer neighborhoods with nicer education systems. Meaning they learned more. And, then my school didn't take education as serious as they could have. Like, yes, [metropolitan city] education, public system is like right here and mine was a little higher. But it wasn't where it needed to be coming to [university], which is a PWI. So, she didn't feel like I was prepared. My work ethic would eventually let me catch myself up. And, then she suggested that I take developmental Chem class before I took Chem 192, so then I could be caught up. But I'm like that would set me back a semester that I don't have time for. I don't have time to 
be....so that's why I'm in this class. That's why I was in that class struggling because- I

didn't learn what I needed to, to have the tools necessary to be ready. Like the first exam was review for everybody else. But I'm like WHAT, I didn't learn any of this.

All three men in the study had points in the interview where grades dictated their thoughts towards themselves, were a barometer for comparison with others, and in some cases, caused them to make decisions about their majors. Smartness is done to individuals. It's been done to these students; in one- form or another, they have received the message that what happens in school determines their smartness. Because it is clear that some of the schools that they have come from have not given them a fair chance to experience school without dominating practices, it is a false narrative that what happens in school can determine one's smartness.

The next section describes other students in the study who find themselves in a tug of war with making meaning of grades.

\section{Duality of Grades and Schooling}

There is no question that smartness and grades were interchangeable for Malcolm.

However, Cece teeters back and forth with the idea that her intelligence is not the sum total of the grades she earns. She understands the weight of grades and feels great when she earns good grades, but she tries to situate them as not having total power to define her.

... I want to ...I'd like to think my grades don't define my intelligence level. But at the same time they really matter to me and they really do define my intelligence level. Like for example I'll say, okay, I failed this exam but I know I'm still smart and I know I still have the capacity to learn. But at the same time when I get an A on the exam and I know that I've aced...that I run through the material and I've aced it, then I'm like okay I'm smart because I learned this, I'm excelling at it.

As much as Cece would like to not have grades be a powerful source of information related to her intellect, she also sees them as strong enough to influence her. Cece shared how she resists the idea of smartness only being reserved for those in college. Her picture of smartness also 
includes her father, who is not a college graduate but his intellectual prowess is held in high regard in her eyes.

I think there's different levels of how a person is considered smart. And, I especially see that with my family...like I think my dad is super smart even though he didn't go to college... like he dropped out of college but he still so smart. Like he loves to read. Like that's how I got my passion for reading from. Like, he's always reading the newspaper and texting me news articles and watching the news. And, I just think he's a really smart man and um you don't necessarily gotta go through a lot of schooling to be smart. Or even be street smart. There's a lot of smart.

In addition to Cece, Leticia considers her mother as a picture of smartness. Though

Leticia dually sees the schooling and grades as the foundation of smartness, she also calls on them to discredit her mother in her intellect.

... and she's smart to me in life ways. Like she () in school got her associate degree in medical assistant. To me she is smart... in general. Like I go to her for everything ...not for school work obviously...she doesn't know anything. But like life in general, I just go to her and talk to her I feel like she's more like smarter than I am in situations....like what I want to do. Like, what's a great path like that.

Leticia's mother has been called smart in life ways but has completely been excluded from the idea that she knows anything about general science. Leticia's first year classes were classes that her mother would have been required to take to earn a medical assistant associates. However, Leticia has used her position as a first year student at a university to classify herself as smarter than her mother. She explains her rational by asserting that her mother's attendance at a community college excludes her from being smart in school.

Yeah, but she didn't like...cause all schools are different. She went for medical assistant, I'm going for science. My stuff is different from hers. She learned like certain things...like I think she went to a community college. So my stuff's a little bit harder than hers.

At the time of the interview, Leticia had just completed her first semester in college while her mother, who was a medical assistant, having completed a number of college courses the 
sciences. However, it is difficult for Leticia to see her mother's intellectual strength in school because her mother earned what Leticia considers a lesser degree from a lesser academic institution.

Finally, Jacob notes that he believes he is smart, but as stated earlier, he has decided to change majors because of the grades that he earned and the complexity of the subject. He holds to the idea of his smartness, but excludes himself from being smart in science because he does not have the natural ability to perform in the subject area. However, when Jacob isolates what he believes smartness is, he is able to move outside of the perimeters of schooling to explain a new rational for smartness. Smartness, in Jacob's terms, is about curiosity.

Well me...let me see... since I was little I was always logical. More creative type of person. I was the person who would build lego building in my room. Cause I could understand the instructions. Like, I think what made me smart was not only fact to determine what's real... whats fact, what's not...and what's opinion. Curiosity is what made me smart. I think ...that's the real reason why I'm smart. Cause curiosity made me smart.

In addition to curiosity, Jacob speaks of what it meant to be smart as a child. While other students looked to grades and school as their way of defining smartness in their youth, Jacob explains smartness is scientific for him in a way.

Like everything...observing people talk, what's on t.v., what my mom is doing. Just observing everything I can... and make it determine a pattern. I think that's like the main reason and making a pattern. And kind of ... a sort of algorithm in my head, so to speak.

Creating an algorithm in his head of patterns was vital for Jacob as he used it to survive a dangerous situation. Jacob encountered a bullying situation as a child that was constant; Jacob's algorithm of survival allowed him to outthink his antagonists.

It was constant and I didn't know how to stop it. After observing the constant...this constant thing that was going on...I had to make a pattern and kind of find a solution for it. What time they walk in the building, what time they walk out the building? What time they go to lunch? What time do I leave lunch? What time do I enter the class? What time do we cross each other in the hallway? And, come up with a solution on how to avoid the 
situation. And, when I have the same class with them...determine the best way to not have contact with them.

Jacob's use of critical thinking, problem solving, and strategic thinking positions him to claim all rights to being smart. Although he says he is smart verbally and has demonstrated smartness in a frame outside structural forms of smartness, Jacob remains plagued by the idea that he is not earning good grades in science and does not believe he is naturally good enough for it. I argue that the same critical thinking, problem solving, and pattern finding can be applied to STEM, but if it will ever be, Jacob will have to rethink how he sees himself in relation to bad grades and smartness in science as a natural talent. Murrell (2007) would argue that Jacob needs the agency to reject the notion of natural ability to perform in science. This rejection would mean that Jacob would take back the power to define who is and assume his own definition of smartness to govern his academic identity.

The students in this section have clearly determined that they see smartness as being a part of the schooling process and have found ways outside of school practices to determine either their smartness or the smartness of people they value. The next section specifically explains where students are in relation to the Academic Identity Continuum.

\section{Academic Identity Continuum}

The stories of the first year African American STEM students in this study reveal ideas and beliefs about themselves that correlates with schooling experiences. As stated in the previous chapter and section, teachers, expectations, curriculum, and grades have had students believing one way or the other about their identity. This section introduces Academic Identity Continuum, my proposed framework that shows in modes how and what the students of this study have believed about themselves based on their experiences with schooling. The four modes on the 
continuum are Academic Identity Crisis, Academic Identity Conflict, Academic Identity Contingency, and Academic Identity Consciousness.

\section{ACADEMIC IDENTITY CONTINUUM}

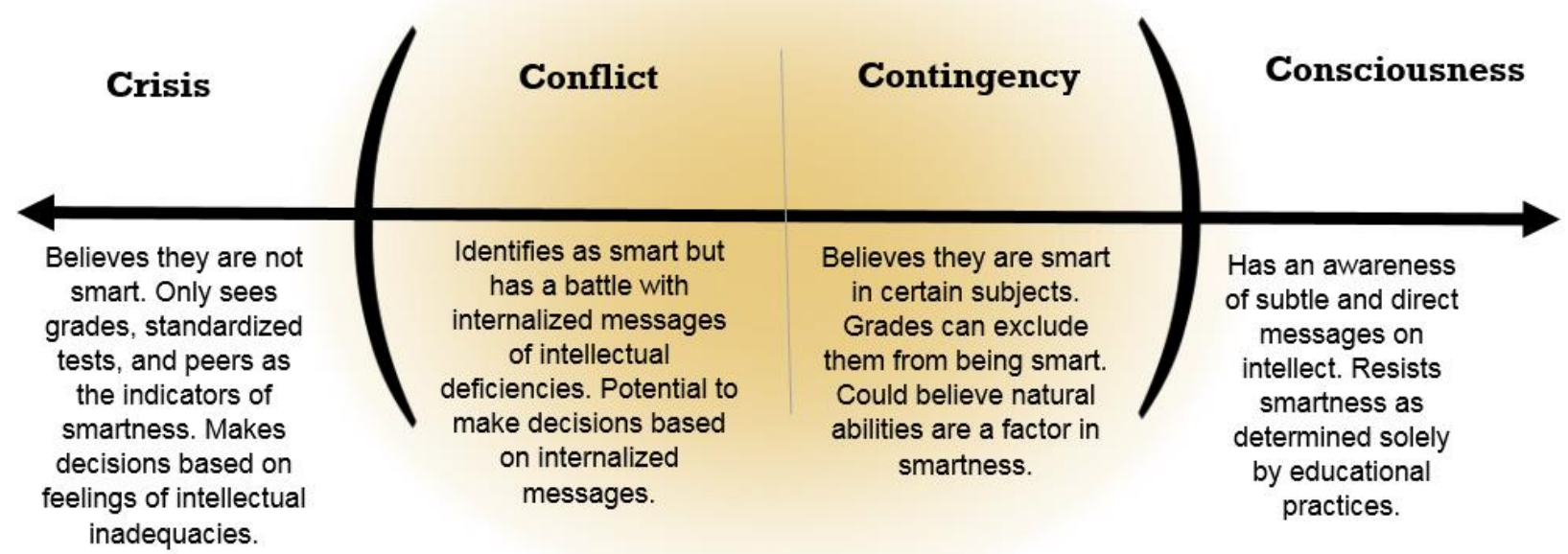

Figure 1. Academic Identity Continuum.

\section{Identity Crisis}

A student in Academic Identity Crisis mode is one who solely see grades, standardized tests, and peers as the indicators of smartness. Nothing can convince this student that they are smart, unless they receive excellent grades. The presence of average grades is an automatic message to the heart and mind of the student that he or she cannot be considered smart. The absence of perfect grades is automatic exclusion from smartness. Students in crisis have personally penalized themselves for not earning perfect grades and subsequently alter their behavior and decision making.

The student from the study who exemplifies the characteristics of this mode is Bruce because he has internalized the idea that grades and standardized testing are the sole determinants of his 
intelligence. He not only argues against being smart because of his grades, but this belief has moved him to change his major.

I mean, yeah. Like smart people don't go for C's, you know? Like maybe I should like try to settle for something easier.

Bruce originally wanted to attend graduate school for pharmacy, but because of a rejection from a previous school, his ACT score, and grades, he expected that if he even pursues a pharmacy degree, he eventually would be academically dismissed from the program.

Well like, pharmacy school is harder. So I have to try harder, then it just won't work out. So, I would probably not get in because of the admissions test. I would just like... get kicked out because I didn’t do well enough.

Another reason Bruce is considered to be in crisis is his constant state of comparing himself to other students from high school and college. These comparisons are based on assumptions about how well other students are doing and a perceived appearance of intelligence of what appears to be his Caucasian counterparts. Bruce is in a position to always downgrade himself if his judgement about his smartness is in comparison to those who have an appearance of smartness.

\section{Identity in Conflict}

A student categorized in the Academic Identity in Conflict mode is able to acknowledge that he or she is smart. However, these students have an internal battle that reminds them of all of the messages that they have received over the course of their educational career. Moving past these messages is hard because they have been internalized. Students in this mode can have positive external affirmations about their intelligence but their grades tell them a different story. It is difficult to determine who and what they can believe. In difficult times, students in this mode can be taken back to a place where they remember the pain of their educational experience 
that taught them not to believe they were smart. They want to believe the best, but many times, this is a difficult task.

The student from the study in conflict is Jamiya. Her grades discouraged her to the point that she decided to quit trying while continuing to go to class. She started to contemplate changing majors during this time.

I was literally coming to class, didn't take notes. I didn't even bring my book bag. I just sat there. Looked at her write on the board and waited for the 50 minutes to be up. And, I was like alright...if I'm not passing this math class then clearly I can't go into this major because you need math. And, you need to be good in math. So I was like alright maybe I should be pick something else right about now.

The conflict also entails fighting past experiences with teachers and not being able to trust teachers' true intentions. Jamiya believed that she would encounter a professor who was not well meaning and might treat her like she was stupid. However, she had an experience with her math professor that proved to be opposite of what she expected.

My math class. Like my teacher was telling me I was one of the best students. And like, I really wasn't believing that because um, I wasn't doing well in the class. But because I was the only one really trying like ask questions and like I was trying my hardest to try and understand what she was teaching. I was like maybe I don't want to give up on this even though I'm not doing good in this class. If she's saying that I'm doing good in her eyes as a student then all the means to push forward, and try my hardest.

Her math professor mentioned that she was amazed by the way Jamiya caught on to concepts. Jamiya's math professor saw Jamiya's abilities, but it was difficult for Jamiya to recognize what the professor saw because of the trauma she endured in school. During the interview, Jamiya realized the truth of her experience, which elicits feelings of stupidity and regret. Jamiya realized she had a choice to fight through those previous feelings.

Cause I feel like, thinking about it now... it didn't have to be that way and like...I'm putting myself in a predicament that I'm making it that way. And, that it just seems 
foolish now that I'm doing that to myself. When I could be doing way better than I am right now. It makes me feel a little...stupid because like...your past doesn't have to determine who you are. But, so far I've been letting it determine who I am. It didn't have to be like this and I chose for it to be like this.

Jamiya recognized that she had a traumatic past in her educational experiences, but she also realized that she has more power than she previously acknowledged. Jamiya determined to take the power back from her experiences. Murrell (2007) would argue that Jamiya has the agency to take this power back.

\section{Identity Contingency}

Identity Contingency refers to students who believes they are smart until they run into a subject area in which they experience difficulty. Smartness still hinges on grades for a student in this mode. Students in this category could easily move from contingency to crisis as they believe that grades define who they are. Malcolm is the student from the study who best fits identity contingency.

I don't know that I am in chemistry. I feel like I'm smart in every other subject that I've taken or that I've been in. Every other classroom, once I've been to tutoring, office hours, or studied...I figured it out. Like all of my other grades are like amazing. I'm here doing what I said I was going to do except for one class where I don't feel smart because I do all the right things but still not getting the right answer.

He even considers that not being smart in chemistry could be a biological construct. The contingency for Malcolm also includes where his natural talents begin and end. He believes they end with chemistry.

....you know how one person may be good in basketball and another person might be good in track. It's not because one is more smart than the other...it's simply this is my talent and that is your talent. So, I feel like maybe some people's brains are geared towards being better at science than others. 
While Malcolm subscribes to the idea that he may not be naturally suited for chemistry, he speaks about his white counterparts who are earning A's in the same class. He expresses frustration that he puts in a great deal of effort and time to only return with average grades. On the other hand, he sees smartness in one of his African American friends and explains the difficulty she had in a biology course and ended up turning her grade around in the class.

I watched her do it. I followed her every step of the way like...best friend go' head...best friend you got this. Like when she failed the first test, she was so defeated ...I'm like no best friend we are not about to give up we about to show'em. She had the same work ethic mindset as me. We are here for a reason. We about to show why we're here. And, I see her 9 am classes, she's there every time. Like, she works hard.

Malcolm can see smartness in his white counterparts earning high grades and his African American friend who turned her grade around from a failing grade to above average grades. Malcolm attributes her turn around to hard work. He also notes that they have the same type of mindset to work until they get the results they desire. The power of grades overshadows the power of his mindset. For this, Malcolm has excluded himself from being smart in chemistry. This is the same mindset Malcolm's mother told him that he must have because she believed his school did not adequately prepare him for the rigors of college education. Although he is aware of the truth of his previous educational experiences and recognizes the inequities that caused him to have to work harder than some of his peers who were exposed to courses that aligned with college curriculum, Malcolm still used his grades in chemistry to determine his intellect and academic capacity. He is not in crisis because although he is earning great grades in his other classes and average grades in his chemistry classes, he is determined to be a dentist and will continue in the pursuit of this degree. 


\section{Identity Consciousness}

A person at the Identity Consciousness level has an awareness of the subtle and direct messages on intellect but is committed to believing in his or her academic development. Students in this mode consciously decide not to let society's definition of smartness become their personal reality. This level can be classified as a form of resistance. One student from the study exhibits resistance at the Academic Identity Consciousness level. Miracle speaks of what she believes it means to be smart. She notes that smartness is not about grades and solely what you know.

I think what it means to be smart is to have knowledge about not just what you're doing but like if you ...don't know what you're doing... problem solve...it's skill...to be smart it's more so than what you know. You know...more skill, more like personality trait, decision making. That's being smart to me...And I feel like ...people call me smart because I try. Because that's part of the decision that I make for myself. You know I don't try...I don't give up...I try to push through when something gets hard. I will try to learn it myself. If it's still hard I do reach out for help. If it's still hard...I just keep finding sources to help me before I'm actually like forget it. And, I think that's part of me being smart. That's part of being smart...just because you know a lot of stuff...like teachers...I understand why people would say they are smart. They know a lot of stuff... you ain't all that to me.*** Laughter

Miracle's definition of smart includes decision making, problem-solving, being determined, and being resourceful. She rejects the notion that practices in school are the sole means for defining smartness. She believes she is smart because she embodies these characteristics. Miracle deeply values not giving up in hard moments, no matter the difficulty of the task, which is the way she approached her first semester in college. Miracle explained how she decided to handled her chemistry class when she ran into challenges.

I love chemistry. But the chemistry class... I want to say...teacher wise that was like one of my worst experiences. It was hard for me to pick up on the way that she was teaching. I would go to class somedays and be like what is she talking about...like what is she talking about. I don't get it... I don't even see a point in this right now. But, I made it easier for myself cause I went home and taught myself. I didn't just leave it at that I was trying to get it. I was trying to teach myself and understand and watch videos on YouTube. And, after I did that I basically put in the work and I got it ...boom. 
Miracle also shared that she has a strategy when she becomes overwhelmed with life and school. She is sometimes tempted to change her views about her intellect based on a combination of difficult times and difficult challenges.

At times, my vision... when my vision get a little blurry and put other people's definition of smart to me, then it be like...man you ain't that smart. Cause all this stuff is hard to you. It's hard. It's hard. But, I run into a lot of hard stuff, but that ain't ever stopped me from being smart. Because, I'm still trying.

Miracle fights against using the traditional definitions to overshadow her personal beliefs about her intellect. This safeguarding protects her from succumbing in tough times with her STEM courses. Miracle also recognizes that there are exclusionary practices that she expects to meet when she starts her career in pharmaceutical research.

Yeah, because I feel like that's why it bothers people that an African American woman can do stuff like find a cure, because their definition of smart... when they think of smart they don't think of African American woman, they think of probably, white male.

Miracle cannot allow the dominating discourse around who can excel in STEM be the determining factor for her belief in her intellectual abilities 


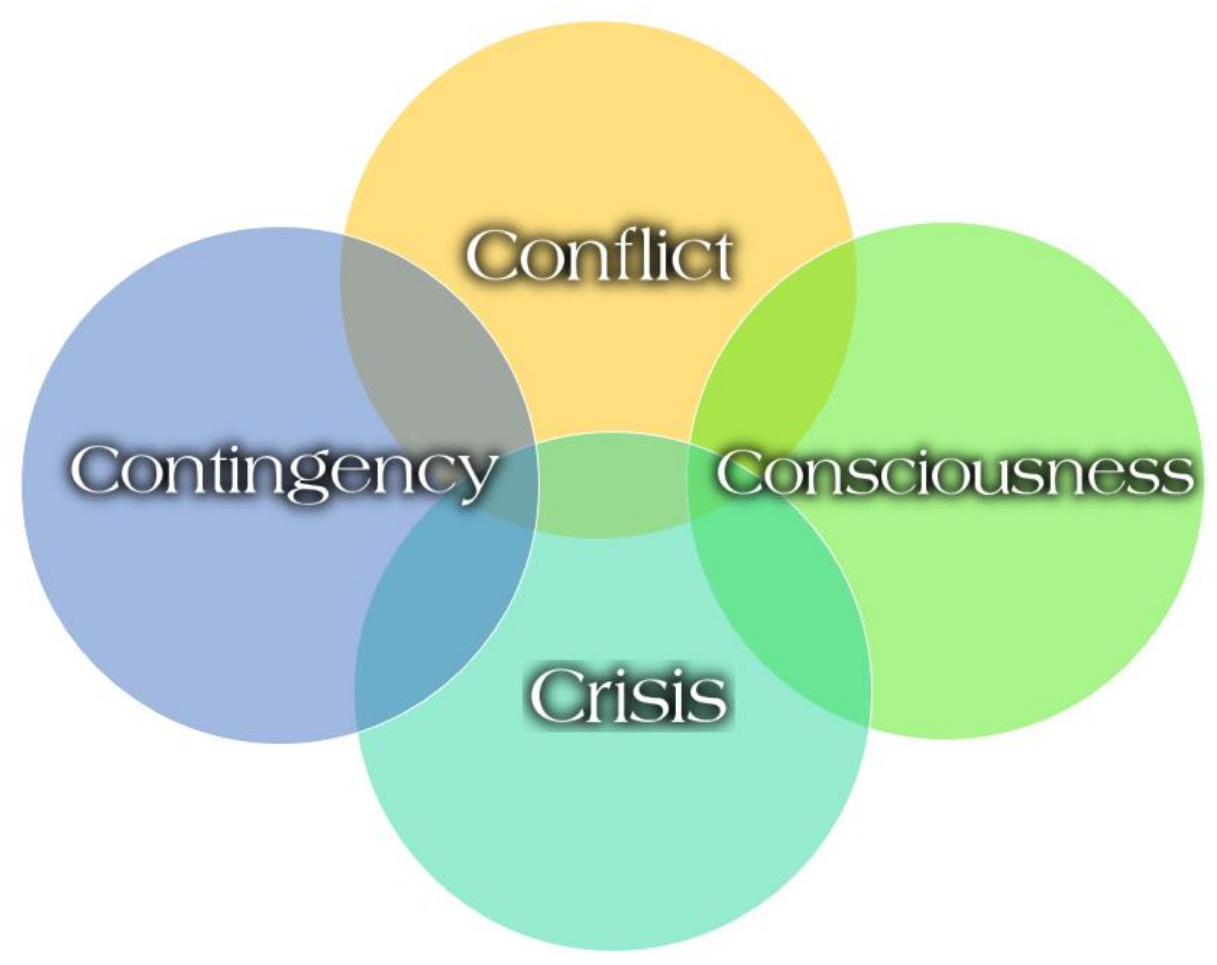

Figure 2. Academic Identity Venn Diagram.

\section{Chapter Summary}

Students' thoughts of self are influenced by a variety of educational interactions and school experiences, with peers, friends, and educational leaders (Skipper, 2005; Schlosser \& Sedlacek, 2001; Hatt, 2012). For the students of this study, grades significantly influenced their academic experience and identity. According to Hatt (2012), smartness is "something that is done to others (students) as a form of social positioning. Smartness is used as a tool by some not only to determine the social identities of others, but to make sense of their own identity" (p 439). In this study, grades serve as a positioning mechanism for students to believe either one way or another about themselves.

One of the major issues with many students who define themselves negatively by grades is that several students in this study come from schools with structural issues that directly impact 
the quality of education many of them have received. The majority of the students in this study hail from primarily African American college preparation schools and took AP courses, but those classes did not align with a college curriculum. Structurally, there is a disconnect in their high school academic experience. By the time many African American students enter their first year of college, they have had many experiences that have shaped them; some of which are discriminatory and racially biased practices within the PK-12 system (Winn, 2011; Wilson, 2014).

In the case of many students in this study, their PK-12 experiences have directly influenced their experiences in college. Hatt (2012) notes the ways we come to understand ourselves within and in relation to the institution of schooling and how this identity shapes our self-perceptions of efficacy, ability, and success in relation to academic potential, performance, and achievement ( $\mathrm{p} 439)$. In one way or another, the study participants have received the message that what happens in school determines their smartness. Thus, the students are left with a false narrative that what happens in school determines one's intellectual capacity. Without agency, students are left to believe the false narrative intended to dominant them and their thoughts of self. 


\section{CHAPTER VI: CONCLUSION}

\section{Introduction}

A long history of assaults, mistreatment, and marginalization has plagued the experiences of African American learners (Anderson, 1988). From slavery to eugenics to Jim Crow to resegregation, African American learners have been positioned as the lesser race and, more dangerously, an intellectually inferior race (Gould, 1981; hooks, 2003, Valencia, 2012). There is evidence that racist ideology that purports African Americans as genetically inferior and thereby, intellectually deficit can be seen working in the policies, procedures, systems, and structures within American education (Valencia, 2012; Mutegi, 2013). The human social constructs of race were built on white supremacy and used as calculated attempts to assassinate the minds of the African American people (Gould, 1981; hooks, 2003, Valencia, 2012). Amidst this harsh reality, a resilient people has pushed back against hate, bigotry, and racism (Bullock, 1967; Webber, 1978; Williams, 2005; Hoff, 2016).

The social construction of race has tainted what should be a non-biased, equity based, and neutral education system where students of all races have the right to excellent teaching, rich curriculum, and abundant resources. Critical Race Theory seals the reality and permanence of racism in American society, legal system, and education system (Harper, 2009; Taylor, Gillborn, \& Ladson-Billings, 2009). Because of this reality, the most innocent citizens are in danger of being shaped in an educational environment that does not protect them mentally or emotionally. There is a moral obligation to seriously care for students not only in the sense of physical safety, but for the student as a whole. We are obligated to respond to the present needs of our current youth, keeping in mind the legacy of social and racist ills that influence the educational system. 
The previous chapters laid the groundwork for considering the hegemonic practices that have met African American people and learners in each era, from the days of educational exclusionary practices during slavery to contemporary times. The previous chapters also pointed to the notion that the students in this study had experiences that negatively impacted their first year college experiences and academic identity. This chapter reviews the original research questions, provides critical reflections of the project, and offers implications for the study as well as a future research agenda.

\section{Purpose Statement and Research Questions}

The purpose of this study was to learn, through the lived experiences of first year African American STEM students, how their high school experiences shaped beliefs about self and intellect. The questions that guided this study are below:

Guiding Question: What is the nature of the academic identities of African American college STEM majors and their connection to discourses of ability during their first year?

1) How do African American STEM students reflect and describe their high school experiences?

2) In what ways did African American students' schools and educators contribute to their selfperceptions about their intellectual abilities?

3) In what ways do the messages within their first year of college replicate or differ from the messages first year African American STEM students received about their intellectual abilities from high school?

The results of this study determined that the students had a number of experiences they consider significant to their academic development. School experiences, whether positive or negative, were classified through the following significant sources: teachers, tracking, access to quality 
curriculum, standardized testing, and grades. These sources led as the students discussed how they felt about their experiences in high school, especially regarding their development as STEM learners. Students identified four ways educators contributed to their self-perceptions regarding their abilities in STEM. These four significant ways were teacher biases, and teacher expectations, the ways that teachers moved outside of their in-class responsibilities to meet students at their point of need, and utilized pedagogical methods that caused students to be inspired about learning STEM.

The results of this study did not reveal a strong answer for question three, as it did with questions one and two. As first year students, the students of this study had classes in large lecture halls where there was not much opportunity to gauge the culture of their STEM departments. These courses were also general education courses, which means many students of different majors were enrolled in them. Students were not immersed in the culture of their departments during they first year. They were unable to speak to the culture or readily identify replicating or differing messages. 
Table 1

Participant Profiles

\begin{tabular}{|c|c|c|c|}
\hline Name & $\mathrm{K}-8$ & High School & Identity \\
\hline Cece & $\begin{array}{l}\text { Private school, low } \\
\text { income, } \\
\text { predominantly black } \\
\text { students, low } \\
\text { expectations }\end{array}$ & $\begin{array}{l}\text { Public, wealthy, } \\
\text { predominantly white, } \\
\text { access to quality } \\
\text { curriculum, tracking }\end{array}$ & $\begin{array}{c}\text { Contingency and } \\
\text { Consciousness }\end{array}$ \\
\hline Bruce & Did not mention & $\begin{array}{c}\text { Public, } \\
\text { predominantly white, } \\
\text { access to quality } \\
\text { curriculum }\end{array}$ & Crisis \\
\hline Jacob & $\begin{array}{l}\text { Moved to different } \\
\text { schools }\end{array}$ & $\begin{array}{l}\text { Public, } \\
\text { predominantly black, } \\
\text { lacked access to } \\
\text { quality curriculum, } \\
\text { tracking }\end{array}$ & Conflict \\
\hline Jamiya & $\begin{array}{c}\text { Public, } \\
\text { predominantly black, } \\
\text { low expectations, } \\
\text { tracking }\end{array}$ & $\begin{array}{c}\text { Charter/College } \\
\text { Prep, predominantly } \\
\text { black, arbitrary AP } \\
\text { selection }\end{array}$ & Conflict \\
\hline Leticia & $\begin{array}{l}\text { Moved to different } \\
\text { schools }\end{array}$ & $\begin{array}{c}\text { College Prep, } \\
\text { predominantly black, } \\
\text { lacked access to } \\
\text { quality curriculum }\end{array}$ & Contingency \\
\hline Malcolm & $\begin{array}{c}\text { Private, } \\
\text { predominantly black, } \\
\text { high expectations }\end{array}$ & $\begin{array}{c}\text { Private, } \\
\text { predominantly black, } \\
\text { lacked access to } \\
\text { quality curriculum, }\end{array}$ & Contingency \\
\hline Miracle & $\begin{array}{c}\text { Public, } \\
\text { predominantly black, } \\
\text { high expectations }\end{array}$ & $\begin{array}{l}\text { Charter/College } \\
\text { Prep, access to } \\
\text { culturally relevant } \\
\text { courses, high } \\
\text { expectations }\end{array}$ & Contingency \\
\hline
\end{tabular}




\section{Critical Reflections}

\section{Academic Terrorism}

The student stories in this study challenged me to think deeply about the power that lies in the educational experience as well as the power that lies in the student's agency. One of those stories was Jamiya's. She introduced herself as a struggling student while other students led discussing their schools, parents, and being smart. Jamiya's sense of identity was tied closely to doing poorly in school. At the point of her interview, Jamiya was failing all of her classes and had stopped attending them on a regular basis. She settled into discouragement and despair, particularly in the mode of academic identity conflict.

Of all of the students, Jamiya had one of the most traumatic educational experiences in the study. Kindergarten was the scene of her first experience with what I call academic terrorism. For numerous reasons, I consider what transpired in school with Jamiya as a form of terrorism. The harmful method of tracking gave Jamiya a detailed look at the dichotomy of the "smart" class and the "dumb" class by virtue of testing. Jamiya's explanation of the system shows that members of the school, peers included, knew who was "dumb" and who was "smart" by teacher association. The high quality, highly coveted teacher was assigned to the smart class. The "dumb" class was left with a teacher and curriculum that paled in comparison to their counterparts. She recognized the difference between the treatment of students in the "dumb" class and the "smart" class, as she experienced both because she tested into both at different times. Jamiya also felt the label of her teachers before she could establish herself at her elementary school. Jamiya spoke of the consequence of being the younger sibling to a brother and sister who performed poorly academically. From very early on, she remembers that she was not smart based on tests, class placements, teacher labels, and low expectations. One major reason I have coined Jamiya's 
educational experience as academic terrorism is her account of teacher bullying by way of consistent, daily nitpicking and calls home to her parents. Jamiya never believed her teachers had the best interest for her or believed the best in her. She was concerned because her brother, sister, and many other students that attended her grammar school did not go on to high school. Not only were her concerns heightened, but they were fueled by teachers who Jamiya said expected her and her peers to be "on the corner selling something."

Jamiya's transition to high school was lifesaving and life changing because she was able to see herself differently through the lens of different teachers. These four years of school were positive and powerful years of transition, but they did not prove strong enough to erase the traumatic past that was part of her educational journey. Jamiya identified the feelings of despair that she felt in her first semester of college were similar to her feelings of despair during her first years of schooling. Her recollection of interactions with teachers, memories of being mistreated, and feelings of being othered and put down all speak to the terrorizing experiences within education. Jamiya's truth is that she never expected to attend college.

I wonder about the experiences of other students who walked away from school after attending the same elementary school that Jamiya did. Were they terrorized to? Did their academic futures get cut short at the hands of a system of terror? Answers to these questions cannot be found in this study, but the research is clear that African American students are disproportionately suspended and stuck in a school to prison pipeline (Wilson, 2014, Winn, 2011). As much as terrorism is against the law and requires investigation of responsibility, I equally call for the investigation of African American student experiences and the practices and people who are guilty of such acts. Insomuch as there is guilt, there should be consequences. 


\section{Shift Back to Consciousness}

Of the students in the study, Miracle had a follow up conversation about the findings of my study, in particular her contributions. I opened our meeting with reading my introductory narrative of her in the study. Miracle responded positively and was pleased with how I captured the essence of her story and person. I then moved to the Academic Identity Continuum diagram and introduced each mode to her. When asked what identity in which she should have been placed, she noted consciousness or conflict.

During our discussion, Miracle shared that the second semester of her college experience was fairly difficult because of the pressure of being on probation. The pressure started to affect her, and she wondered if she wanted to continue to fight, not only get back into good academic standing, but to also fight for her mental fortitude. In her resolve, Miracle determined no other options existed except to fight, for both. Miracle exhibited both conflict and consciousness.

Critical Race Theory research challenges researchers to provide opportunities for transformation. Therefore, I focused the second part of my interview with Miracle on empowerment. I allowed Miracle to not only see the continuum and share her thoughts about where she was, but also shared my interpretation of where she was in our first interview. My goal was to empower Miracle, in the tough spot of academic probation, to remember who she was, a person who exhibited a conscious academic identity. We took turns reading the narrative; she read her words, and I read my commentary expounding on her words. At the time of the second interview, Miracle was fighting to move from conflict to consciousness. The critical reflective activity that I am calling qualitative table read allowed Miracle to reconnect the words she spoke as well as to remember who she was and the agency she possessed to resist. 


\section{Implications of a Broken System}

At some point in the research, each student was at a point of deciding about who they were based on a test score, grade, class, or teacher. In some cases, the decisions that students were prepared to make about themselves were based on what I consider a broken educational system. CRT shows the brokenness of the educational system with the racist practices that directly impact African American students. The Educational Debt shows the brokenness of the educational system by explaining the historical, economic, and sociopolitical debts that leave African American children at a disadvantage (Ladson-Billings, 2006). The brokenness of our education system is evidenced through the consistent talk of educational reform, whether students are being asked to race to the top or over tested so they will not be left behind.

I am arguing the danger in a broken system that defines the identities of students, in particular African American students. I am arguing against a broken system with just as much segregation as pre-Brown v. Board schools, having the power to cast identity on students of color. I am arguing against the brokenness of schools with low expectations and a lack of rigorous curriculum. I am pushing back against standard based testing that paints smartness with a broad brush while ignoring the unequal practices in schools populated with students of color. I am pushing against the idea of the false narrative that African American students are at-risk. I am fighting against a system that has repeatedly proven that it is not as valuable, as smart, as viable for equal, empowering education. Therefore, the kind of education that African American students are meant to receive is not intended to build them up; in fact, it is meant to tear them down.

\section{Future Research}

The next step in my research agenda is to continue to study academic identity by understanding the Academic Identity Continuum theory further. I would like to extend the follow 
up work conducted with Miracle and Jamiya, which I have called "qualitative table read" with the other students of this study. The follow up work could happen at the beginning of their second year in college as an opportunity to expose them to ideas of resistance and their ability to do so. I also expect to expand the participants of my work to include other marginalized and racialized student groups.

Answering the fourth question in the study about messages from the previous educational experiences being replicated in higher education presented some challenges considering the students did not have enough experience in their departments. The first year is a critical year for students to make decisions, but to fully understand how the messages of their previous experiences impact their college career, having participants who are sophomores, juniors and seniors will provide more information about the culture of their departments, smaller classroom dynamics, research labs, and professional development opportunities.

I also would like to expand this research to include other LSAMP programs in the Alliance. Fourteen schools and one government laboratory are in the Alliance. I would like to expand my study on the Academic Identity Continuum to test it with other African American students throughout the state. Expanding the scale to include more students from different institutions would help to test my theoretical framework's validity.

In addition, I eventually would like to create a curriculum that would speak to the development of academic identity of African American students for coordinators to implement with their first year students. Many LSAMP programs focus on building students' academic skills through providing workshops study skills and test taking as well as research and mentorship opportunities. These aspects of the program should remain in order for students to build their professional profiles; however, space and time also should be dedicated to strengthening and 
developing the identity of students. The ultimate goal of such a curriculum is to understand how to move students from one mode on the continuum to consciousness.

Students are in a position to decide about STEM during the first year. It is important to hear from students how these decisions are made, what factors influence these decisions, and how to counter the narrative that strongly suggests that African American students do not belong in STEM. Finally, I would like to further explore the idea of academic terrorism as a means for identity dismantling. With that, I remain curious regarding if and how schools name, investigate, and adjudicate instances of academic terrorism. Even more, I am interested in how accountability is handled for the larger structural issues, beyond a single person or a single school that promotes academic terrorism.

\section{Chapter Summary}

This study has left me, as a researcher, with many questions about the educational system. One question that reverberates is how can we expect our students to go through 12 years of underfunding preparation, low expectations, unqualified teachers, and not expect these unfair practices to negatively impact the first year college experience, much less the student's psyche. We cannot expect a student who has come from a school or school system with disparaging educational practices not to have any kind of mental, psychological, or spiritual repercussions. What do we have to say to our African American STEM students who are excited about studying STEM, have dreams of being doctors, researchers, computer scientists, yet they have not been exposed to the curriculum that prepares them to fight for their dreams? How do we account for the African American students who have high aspirations for STEM, but their attainment of STEM does not compare in the slightest? What are we prepared to tell these students when they sit in classrooms, advising seats, and LSAMP coaching sessions if they encounter troubles in their 
STEM classrooms? Will someone with an understanding of the system be willing to walk a student through an empowering conversation about who they are and who they can be? How can we undo the lingering residue of low expectations and teacher bias for students of color who are studying STEM? The first year of college has been called the most critical year for students. This is the year that students make decisions. And, they make decisions that can impact their academic and career trajectories.

Another question that continues to befuddle me is the reason the educational standards are different for African American students. How does it remain acceptable to lean on statistical data that puts African American students at the bottom of the "intellectual" hierarchy chart but not acknowledge the conditions by which they experience school? Why are the expectations low for African American children? Can we explain why the numbers are dismal for African Americans? Are we willing to explain why? Many will say, publicly or privately, that something is wrong with the African American mind, African Americans do not have the same mental capacity as white children. And, even more, innocent children have been made scapegoats for the racism and injustice that encapsulate the education system.

\section{A Call to Action}

I end my research with a call to action rather than a summary of the work I have done. The implication of a broken system is certainly not a solo fight; I also challenge those who lead in the broken system to be critically relevant educators. The list of people who should have access to this research includes, but is not limited to, LSAMP coordinators, high school counselors, college advisors, college professors, teachers, administrators, pre professional professors and trainers, policy makers, etc. I challenge these key leaders to understand the power and responsibility to 
empower students, whether they are aware or not, to understand that they are in a broken, racist system that seeks to cast an identity of inferiority on them.

I challenge my fellow leaders, along with myself, to be vigilant in our work, writings, program development and assessment, staff meetings, and decisions of practice and policy. Every leader should see it as their duty to empower African American students to successfully navigate schools and universities while keeping their identities intact. More than having an intact identity, I would like to argue for an academic identity that is conscious of the brokenness with the system but armed with resources, networks, supports, and counter narratives that keep African American students in an empowered state. This work is critical because students have to be empowered to silence the voices, the practices, and the disempowering moments learned within a broken system. Students have to utilize their value system that builds and sustains their identity. This kind of work is very important because people's lives, futures, legacies, and children are connected to their identities. Any student who has experienced brokenness in the form of trauma in school could be in jeopardy of being in a state of crisis, conflict, and contingency until he or she faces the truth about the broken system and the broken narrative constructed for his or her identity. Key leaders committed to being culturally relevant are paramount in this kind of necessary work - to help students move to and maintain an academic identity that is conscious and empowered to pursue their educational goals amidst a broken system. 


\section{REFERENCES}

Adelman, C. (1999). Answers in the toolbox: Academic intensity, attendance patterns, and bachelor's degree attainment. Washington, DC: U.S. Department of Education, Office of Educational Research and Improvement.

Anderman, L. H., Freeman, T. M., \& Jensen, J. M. (2010). Sense of belonging in college freshmen at the classroom and campus levels. The Journal of Experimental Education, 203-220.

Anderson, J. D. (1988). The education of Blacks in the South, 1860-1935. Chapel Hill: University of North Carolina Press.

Ansalone, G. (2006). Tracking: A return to Jim Crow. Race, Gender, and Class, 13(1-2), 144153.

Ansalone, G. (2010). Tracking: Educational differentiation of defective strategy. Educational Research Quarterly, 34(2), 3-17.

Ansalone, G., \& Biafora, F. (2004). Elementary school teachers' percceptions and attudes to the educational structure of tracking. Education, 125(2), 249-258.

Archer, L., Dewitt, J., \& Osborne, J. (2015). Is science for us? Black students' and parents' views of science and science careers. Science Education, 99(2), 199-237.

Au, W. W. (2009). High-stakes testing and discursive control: The triple bind for non-standard student identities. Multicultural Perspectives, 11(2), 65-71.

Baber, L. D. (2014). Considering the interest-convergence dilemma in STEM education. The Review of Higher Education, 38(2), 251-270. 
Barefoot, B. O. (2005). Current institutional practices in the first college year. In L. M. Upcraft, J. N. Gardner, \& B. O. Barefoot, Challenging and supporting the first-year student (pp. 47-63). San Francisco: Jossey Bass.

Basile, V., \& Lopez, E. (2015). And still I see no changes: Enduring views of Students of Color in science and mathematics education policy reports. Science Education, 99(3), 519-548.

Bell, D. A. (2004). Unintended lessons in Brown v. Board of Education. 49(1053).

Bell, L. A. (2003). Telling tales: What stories can teach us about racism. Race Ethnicity and Education, 6(1), 3-28.

Berry III, R. Q. (2008). Access to upper-level mathematics: The stories of successful African American middle school boys. Journal of Research in Mathematics Education, 39(5), 464-488.

Blanchett, W. (2006). Disporportionate representation of African American students in special education: Acknowledging the role of white priviledge and racism. Educational researcher, 35(6), 24-38.

Blustein, D. L., Murphy, K. A., Kenny, M. E., Jernigan, M., Perez-Gualdron, L., Castaneda, T., . . Davis, O. (2010). Exploring urban students' construction about school, work, race, and ethnicity. Journal of Counseling Psychology, 57(2), 248-254.

Bullock, H. (1967). History of Negro education in the south. Cambridge: Harvard University Press.

Butchart, R. E. (2010). Schooling the freed people: Teaching, learning, and the struggle for Black freedom 1861-1876. Greensboro: The University of North Carolina Press. 
Chen, X. (2009). Students who study science, technology, engineering, and mathematics (STEM) in postsecondary education. Stats in brief NCES 2009-161. Washington D.C.: U.S. Department of Educationn, National Center for Education Statistics.

Chen, X. (2013). STEM attrition: College students' paths into and out of STEM fields (NCES 2014-001). Washington, D.C.: National Center for Education Statistics, Institute of Education Sciences, U.S. Department of Education.

Civis. (1993). The public school in its relation to the negro. In J. D. Smith, The benefits of slavery argument. (Vol. Part 2 , pp. 1-37). New York: Garland Publishers.

Clark, M. R. (2005). Negotiating the freshman year: Challenge and strategies among first-year college students. The Journal of College Student Development, 46(3), 296-316.

Cole, D. (2007). Do interracial interactions matter? An examination of student-faculty contact and intellectual self-concept. The Journal of Higher Education, 78(3), 249-281.

Darling-Hammond, L. (2007). The flat earth and education: How America's commitment to equitey will determine our future. Educational Researcher, 36(6), 218-334.

Darling-Hammond, L. (2010). The flat world and education: How America's committment to equity will determine our future. New York: Teacher College Press.

DeCuir, J. T., \& Dixson, A. D. (2004). "So when it comes out, they aren't that surprised that it is there": Using Critical Race Theory as a tool of analysis of race and racism in education. Educational Researcher, 33(5), 26-31.

Dixson, A. D., \& Rousseau, C. K. (2006). And we are still not saved. In A. D. Dixson, \& C. K. Rousseau, Critical race theory in education (pp. 31-56). New York: Routledge. 
DuBois, W. (1968). The autobiography of WEB Du Buis: A soliloquy on viewing my life from the last decade of its first century. Oxford.

Dweck, C. (2006). Mindset:The new psychology of success. New York: Random House.

Edmunds, J. A. (2012). Early colleges: A new model of school focusing on college readiness. New Directions for Higher Education, 2012(158), 81-89.

Engle, J., \& Tinto, V. (2008). Moving beyond access: College success for low-income, firstgeneration students. D.C.: The Pell Institute for the Study of Opportunity in Higher Education.

Feagin, J. R., Vera, H., \& Imani, N. (1996). The agony of eduation: The Black students at White college and universities. New York: Routledge.

Ferguson, P.V. Plessy v. Ferguson (1896).

Finkel, E. (2010). Black children still left behind. District Adminstration, 46(10), 26-33.

Fishcher, M. J. (2007). Settling into campus life: Differences by race/ethnicity in college involvement and outcomes. The Journal of Higher Education, 2(78), 125-156.

Gould, S. J. (1981). The mismeasure of a man. New York: W.W. Norton \& Company.

Guthrie, J. W., \& Springer, M. G. (2004). Returning to square one: From Plessy to Brown and Back to Plessy. Peabody Journal of Education, 1-31. 
Gutierrez, R., \& Dixon-Roman, E. (2010). Beyond the gap gazing: How can thinking about education comprehensively help us (re) envision math education? In R. Gutierrez, \& E. Dixon-Roman, Mapping equity and quality in mathematics education (pp. 21-34). New York City : Springer Netherlands.

Harper, S. R. (2009). Race-concious student engagement practices and the equitable distribution of enriching educational experiences. Liberal Education, 95(4), 38-45.

Harper, S. R., Patton , L. D., \& Wooden, O. S. (2009). Access and equity for African American studnets in higher education: A critical race historical analysis of policy efforts. The Journal of Higher Education, 80(4), 389-414.

Harry, B., \& Klingner, J. (2007). Discarding the deficit model. Educational Leadership, 64(5), $16-21$.

Hatt, B. (2012). Smartness as a cultural practice in schools. American Educational Research Journal, 49(3), 438-460.

Hatt, B. (2016). Racializing smartness. Race Ethnicity and Education, 1-8.

Heilig, J. V., \& Darling-Hammond, L. (2008). Accountability Texas-Style: The proress and learnign of urban minority students in a high-stakes testing context. Educational Evaluation oand Policy Analysis, 30(2), 75-110.

Higher Education Research Institute . (2010). Degrees of success: Bachelor's degree completion rates among initial STEM majors. Los Angeles: Higher Education Research Institute. 
Hoff, P. T. (2016). "Fool me once, shame on you; fool me twice, shame on me': African American students' reclamation of smartness as resistance.". Race Ethnicity and Education, 1-9.

Holland, D., Lachicotte, W., Skinner, D., \& Cain, C. (1998). Identity and agency in cultural worlds. Cambridge: Harvard University Press.

hooks, b. (2003). Rock my soul: Black people and self esteem. New York: Atria Books.

Howard, T. C. (2003). "A tug of war for our minds." African American high school students' perceptions of their academic identities and college aspirations. The High School Journal, 87(1), 4-17.

Howard, T. C. (2008). Who really cares? The disenfranchisement of African American males in preK-12 schools: A critical race theory perspective. Teachers College Record, 110(5), 954-985.

Ishler, J., \& Upcraft, M. (2005). The keys to first-year student persistence. Challenging and supporting the first-year students. San Francisco: Jossey-Bass.

Jackson, A. Y., \& Mazzei, L. A. (2012). Thinking with theory in qualitative research. New York: Routledge.

Kane, J. (2012). Young African American children constructing academic and disciplinary identities in an urban science classroom. Science Education, 96(3), 457-487.

Klopfenstein, K. (2004). Advanced placement: do minorities have equal opportunity? Economics of Education Review, 23(2), 115-131. 
Klugman, J. (2013). The advanced placement arms race and th reproduction of educational inequality. Teachers College Record, 115, 050305, 1-34.

Koyama, J. (2007). Approaching and attending college: Anthropological and ethnographic accounts. The Teacher College Record, 109(10), 2301-2323.

Kozol, J. (1991). Savage inequities. New York: Crown.

Kozol, J. (2005). The shame of the nation: The restoration of apartheid schooling in America. New York: Crown Publishing.

Ladson-Billings, G. (1995). "But that's just good teaching! The case for culturally relevant pedagogy.". Theory into practice, 34(3), 159-165.

Ladson-Billings, G. (2006). From the achievement gap to the education debt:understanding achievement in U.S. schools. Educational Researcher, 3-12.

Ladson-Billings, G. (2009). Just what is critical race theory and what's it doing in a nice field like education? In E. Taylor, D. Gillborn, \& G. Ladson-Billings, Foundations of critical race theory in education (pp. 17-36). New York: Routledge.

Ladson-Billings, G. J. (1999). Preparing teachers for diverse student populations: A critical race theory perspective. Review of research in education, 24, 211-247.

Ladson-Billings, G., \& Tate, W. (2006). Toward a Critical Race Theory of education. In A. D. Dixson, \& C. K. Rousseau, Critcal race theory (pp. 11-30). New York: Routledge.

Lincoln, Y., \& Guba, E. (1985). Naturalistic inquiry. Newbury Park: Sage. 
Luke, A. (1995). Chapter 1: Text and discourse in education: An introduction to critical discourse analysis. Review of research in education, 21(1), 3-48.

Merriam, S. B. (2009). Qualitative Research: A guide to design and implementation. San Francisco: Jossey-Bass.

Mickelson, R. A., \& Everett, B. J. (2008). Neotracking in North Carolina: How high school courses of study reproduce race and class-based stratification. Teacher College Record, $110(3), 535-570$.

Milford, T. M., \& Tippett, C. D. (2013). Preservice teachers' images of scientists: Do prior experiences make a difference? Journal of Science Teacher Education, 24(4), 745-762.

Morris, V. G., \& Morris, C. L. (2002). The price they paid: Desegregation in an African American community. Teachers College Press.

Mulhall, A. (2003). In the field: Notes on observation in qualitiative research. Methodological Issues in Nursing Research, 4(13), 306-313.

Murrell, P. (2007). Race, culture, and schooling: Identieis of achievement in multicultural urban schools. Mahwah: Lawrence Erlbaum Associates.

Murrell, P. C. (2001). The community teacher: A new framework for effective urban teaching. . New York: Teachers College Press.

Mutegi, J. (2013). "Life's first need is for us to be realistic" and other reasons for examining the sociocultural construction of race in the science performance of African American students. Journal of Research in Science Teaching, 50(1), 82-103. 
Naidu, S. (2010). Recruitment restrictions and labor markets: Evidence from the postbellum US South. Journal of Labor Economics, 28(2), 413-445.

Nasir, N. S., McLaughlin, M. W., \& Jones, A. (2009, March). What does it mean to be African American? Constructions of race and academic identity in an urban public high school. American Educational Research Journal, 46(1), 73-114. doi:10.3102/0002831208323279

National Center for Education Statistics. (2016). Indicator 24: STEM Degrees. D.C.: United States Department of Education. Retrieved from https://nces.ed.gov/programs/raceindicators/indicator_reg.asp

National Science Foundation, National Center for Science and Enginnering Statistics. (2013). Woman, minorities, and persons with disabilities in science and engineering. Arlington: Special Report NSF 13-304. Retrieved from http://www.nsf.gov/statistics/wmpd/

Oakes, J. (1985). Keeping track: How schools structure inequality. New Haven: Yale University Press.

Okeke, N., Howard, L. C., Kurtz-Costes, B., \& Rowley, S. J. (2009). Academic race stereotypes, academic self-concept, and racial centrality in African American youth. Journal of Black Psychology, 35(3), 366-387.

Osgood, R. (2010). Education in the name of "improvement" The influence of eugenic thought and practic in Indiana's public schools, 1900-1930. Indiana Magazine of History 106, 106(3), 272-299.

Ostrove, J., \& Long, S. (2007). Social class and belonging: Implications for college adjustment. The Review of Higher Education, 30(4), 363-389. 
Plessy v. Ferguson, 163 US 537 (Supreme Court of the United States May 18, 1896).

Reddy, A. (2008). The eugenics origins of IQ testing: Implications for post-aikins litigation. Chicago: DePaul Law Review.

Rist, R. (1970). Student social class and teacher expectations: The self-fulfilling prophecy in ghetto education. Harvard Educational Review, 40(3), 411-451.

Robinson, L., Harris, A., \& Burton, R. (2015). Saving face: Managing rapport in a problembased learning group. Active Learning in Higher Education, 16(1), 11-24.

Roderick, M., Nagoaka, J., \& Coca, V. (2009). College readiness for all: The challene for urban high schools. Future of Children, 19(1), 185-210.

Rubin, C. (2007). Learner identity amid figured worlds: Constructing (in) competence at an urban high school. The Urban Review, 39(2), 217-249.

Schlosser, L. Z., \& Sedlacek, W. E. (2001). The relationship between undergraduate students' percieved past academic success and perceived academic self-concept. Journal of First Year Experience, 95-105.

Seldon, S. (2007). Biological determinism and the narrative of adjustment: The high school textbooks of Truman Jesse Moon, c1921-1963. Curriculum Inquiry, 37(2), 159-196.

Skipper, T. L. (2005). Student development in the first college year: A primer for college educators. South Carolina: National Resource center for the First-Year Experience and Students in Transition. 
Smith, W. A., Allen, W. R., \& Danley, L. L. (2007). "Assume the position....you fit the description":Psycholosocial experiences and racial battle fatigue among African Amerincan male college students. American Behavioral Scientist, 51(4), 551-578.

Solorzano, D. G., \& Yosso, T. J. (2002). Critical race methodology: Counter-storytelling as an analytical framework for educational research. Qualitative Inquiry, 8(1), 23-44.

Solorzano, G., \& Ornelas, A. (2004). A critical race analysis of Latina/o and African American advanced placement enrollment in public high schools. The High School Journal, 87(3), 15-26.

Stairs, A. J. (2011). Urban teaching in America: Theory, research, and practice in $K-12$ classrooms. Thousand Oaks: Sage.

Stanley, C. (2007). When counter narratives meet master narratives in the journal editorialreview process. Educational Researcher, 36(1), 14-24.

Steele, C. (1999). Thin ice: Stereotype threat and Black college students. The Atlantic Online, 110.

Su, C. (2007). Cracking silent codes: Critical race theory and education organizing. Discourse: studies in the cultural politics of education, 28(4), 531-548.

Taylor, E., Gillborn, D., \& Ladson-Billings, G. (2009). Foundations of critical race theory in education. New York: Routledge.

Terenzini, P. (1995). First-generation college students: Characteristics, experiences, and cognitive development. University Park: National Center on Postsecondary Teaching, Learning and Assessment. 
Thompson, G. L. (2002). African American teens discuss their schooling experiences. Westport : Greenwood Publishing Group .

Thompson, G. L., \& Allen, T. G. (2012). Four effects of the high-stakes testing movement on African American K-12 students. The Journal of Negro Education, 81(3), 218-227.

U.S. Department of Education. (2016, March 16). FACT SHEET: Spurring African-American STEM Degree Completion. Retrieved from ed.gov: https://www.ed.gov/news/pressreleases/fact-sheet-spurring-african-american-stem-degree-completion

U.S. Department of Education Office for Civil Rights. (2014, March 21). Civil rights data collection: Data snapshot (college and career readiness). D.C.: Deparment of Education.

United States Department of Education. (2016). The state of racial diversity in the educator workforce. District of Columbia: United States Department of Education. Retrieved from www2.ed.gov/rschstat/eval/highered/racial-diversity/state-racial-diversity-workforce.pdf

Urrieta, L. (2007). Figured worlds and education: An introduction to the special issue. The Urban Review, 107(116), 107-116.

Valencia, R. (2010). Dismantling deficit thinking: Educational thought and pratice. New York: Routledge.

Valencia, R. (2012). The evolution of deficit thinking educational thought and practice. Hoboken: Taylor and Francis.

Valencia, R. R. (2010). Dismantling contemporary deficit thinking. New York : Routledge. 
Watkins, N. L., Labarrie, T. L., \& Appio, L. M. (2010). Black undergraduates' experiences with perceived racial miccroaggressions in predominantly white colleges and universities. In D. W. Sue, Microaggressions and marginality: Manifestations, dynamics, and impact (pp. 25-58). Hoboken: Wiley.

Watkins, W. H. (2001). The White architects of Black education: Ideology and power in America, 1865-1954. New York: Teachers College Press.

Webber, T. L. (1978). Deep like the rivers: Education in the slave quarter community, 1831 1835. New York: Norton.

Welch, O., \& Hodges, C. (1997). Standing outside on the inside. Albany: State University of New York.

Wenger, E. (2000). Communities of practice and social learning systems. Organization, 7(2), 225-246.

Werblow, J., Urick, A., \& Duesbery, L. (2013). On the wrong track: How tracking is associated with dropping out of high school. Equity and Excellence in Education, 46(2), 270-284.

Williams, H. A. (2005). Self-taught: African American education in slavery and freedom. Chapel Hill: University of North Carolina .

Williamson, J. A. (1999). In defense of themselves: The Black student struggle for success and recognition at predominantly white colleges and universities. The Journal of Negro Education, 68(1), 92-105.

Wilson, H. (2014). Turn of the school-to-prison pipeline. Reclaiming Children, 23(1), 49-53. 
Winn, M. T. (2011). The right to be literate: Literacy, education, and the school-to-prison pipeline. Review of research in education, 35(1), 147.

Woodson, C. G. (1933). The mis-education of the Negro. Washington D.C.: Associated Publishers.

Wright, B. L. (2011). Valuing the "everyday " practices of African American students k-12 and their engagement in STEM learning: A position. The Journal of Negro Education, 80(1), $5-11$.

Zamudio, M., Russell, C., Rios, F., \& Bridgeman, J. (2011). Critical race theory matters. New York: Routledge.

Zamudio, M., Russell, C., Rios, F., \& Bridgeman, J. (2011). Critical race theory matters. New York: Routledge. 


\section{APPENDIX A: LETTER OF SUPPORT, LSAMP APPROVAL}

Dr. William J. F. Hunter

Director

Center for Mathematics, Science, \& Technology

\section{ILLINOIS STATE}

UNIVERSITY

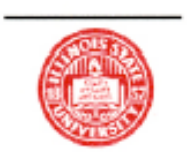

102 CeMaST @. CRC

Campus Box 5960

Normal, IL 61790-5960

Telephone: (309) 438-3089

Facsimile: (309) 438-3592

E-mail: whunter@ilstu.edu

September 13, 2016

Institutional Review Board

Illinois State University

Normal, IL, 61790

Dear Committee Members:

I am writing to offer my support as Principal Investigator of the Illinois State University LSAMP program to the dissertation study of Ms. Christa Platt. Ms. Platt has designed a study that is both rigorous and important and could lead to a much better understanding of the features and experiences that influence the academic identity of African-American STEM students at the undergraduate level. As I am sure you will read elsewhere in her proposal, African American students are severely underrepresented in the STEM disciplines and her analysis of pre-college student experiences and how these students develop a self-concept of themselves as scientists and engineers is vital for overcoming their under-participation.

Ms. Platt has had a long commitment to the ISU LSAMP program and to STEM career aspirations of African-American students. She has been the lead coordinator of our LSAMP program for five years, and has demonstrated unwavering support for students and to providing them with meaningful opportunities. There is no one at ISU who is more qualified to conduct this research, nor is there anyone who could interact with the participants with more sensitivity and insight than her. This study could result in sensitive information being revealed by participants both individually and collectively, but there is no one whom I trust more than MS. Platt to conduct this research thoroughly, thoughtfully and ethically.

Please give her your support as you review her IRB application. If you have any questions, please feel free to contact me.

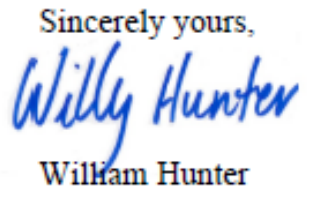




\section{APPENDIX B: RECRUITMENT LETTER}

Date:

Dear

Christa Platt, doctoral candidate in the Educational Administration Program, is conducting a research study to explore the academic identity of first year African American STEM students. Through her research, she hopes to provide greater understanding of how science, technology, engineering and math majors can be supported in their academic pursuits.

She is inviting you to participate in the study. If you choose to participate, you will be asked to complete a two question autobiography of your experiences prior to college and one audio-taped interview that will take place at school and last approximately one hour.

Your participation is voluntary. Your participation with this study is completely separate from your participation in the LSAMP program and will in no way influence your participation in the LSAMP program.

You will receive a gift card after completing the autobiography and a second gift card will be given at the conclusion of the interview. These gift cards will be in the amount of $\$ 10$ each and will be to a local restaurant.

Your name will remain confidential and there will not be any immediate risks associated with your participation in this study.

Your participation will provide greater insight into how to better support African American students in higher education. Your participation would be much appreciated and will hopefully lead to greater success of African American students majoring in STEM fields.

Please complete the survey below to indicate your interest in the study. If you indicate interest, Christa will contact you in a few days to set up a time to discuss the autobiography and the interview that will take place.

Thank you for your time and your interest in this study. Your opinions will be invaluable to the success of this research.

Sincerely,

Dr. Beth Hatt

bhattec@ilstu.edu 


\section{APPENDIX C: CONSENT FORM}

Dear

I am a graduate student under the direction of Dr. Beth Hatt in the College of Education at Illinois State University. I am conducting a research study to explore the academic identity of first year African American STEM students. Through my research, I hope to provide greater understanding of how universities can do a better job supporting the achievement of African American students majoring in STEM fields.

I am inviting your participation, which will involve you completing an autobiography of your experiences prior to college and one audio-taped interview with me that will take place at school and last approximately one hour. Additionally, I will observe two to three Community of Scholar meetings in which you participate.

Your participation is voluntary. You will receive a gift card after completing the autobiography and a second gift card will be given at the conclusion of the interview. These gift cards will be in the amount of $\$ 10$ gift certificates and will be to a local restaurant.

Risks for the study are no more than what you may experience in everyday life. However, if you do become emotional, you are able to withdraw from the study at any point without penalty. In addition, you have the right to refuse any interview questions that you are not comfortable answering.

Your participation with this study is completely separate from your participation in the LSAMP program and will in no way influence your participation in the LSAMP program. Your refusal to participate will not cause you to lose LSAMP benefits or be penalized in any way.

All data will be kept confidential and participant names will be replaced with pseudonyms. All data will be kept in a locked office and a locked filing cabinet.

Thank you for your time and your interest in this study. Your opinions will be invaluable to the success of this research.

If you have any questions about your rights or concerns as a participant in the study, you can contact Beth Hatt via phone at (309) 438-5422 or via email at bhattec@ilstu.edu.

Sincerely,

Christa D. Platt

I give consent to participate in the above study. I understand that my interview will be audiotaped.

Signature

Date 
If you have any questions or if you feel you have been placed at risk as a result of participating in this study, you can contact the Research Ethics \& Compliance Office at Illinois State University at (309) $438-2529$. 


\section{APPENDIX D: INTERVIEW QUESTIONS}

\section{Autobiography Questions}

Thank you for agreeing to participate in this study. Please take a few moments to give a detailed response to the following questions. You can reflect on any experience prior to entering college (elementary, middle school, or high school).

1. Can you describe one day or one event from your past that made you especially feel you could be in a STEM major? Please share a detailed account of where you were, the people involved, and what was said.

2. Can you describe a time in your past when you did not feel like you belonged in the STEM community? Please share a detailed account of where you were, the people who were present, and what was said.

\section{Interview Questions}

Introduce self and explain a little about the study.

1. Tell me a little bit about why you are interested in STEM?

2. Were there people from your past that made STEM particularly interesting?

3. Were there people that made you feel like you did not belong in STEM before you came to college? (Have you ever doubted your ability to major in STEM? If so, what happened?)

4. How comfortable do you feel in your STEM classes? Do you believe you were prepared for your STEM classes?

5. Tell me about the best/worst STEM professor you have had in college?

6. Has there been an experience this semester that made you feel like you belong in your major? Who were the key players?

7. Have there been any experiences that made you feel like you did not belong in your major? Who were the key players?

8. What do you think it means to be smart?

a. Do you believe you're smart?

b. Have you ever been made to feel like you're not smart in school?

c. What did it mean to be smart where you grew up?

d. Who do you think of as smart?

e. In your opinion, is there any such thing as "smartness?" If so, do you believe there are certain individuals who can be smart in STEM majors? 